\title{
Pandangan Masyarakat Terhadap Kebijakan Standar Nasional Pendidikan (Studi Pada Pendidikan Dasar di Kota Tanjungpinang)
}

\author{
Rendra Setyadiharja ${ }^{1)}$ *, Neng Suryanti Nengsih ${ }^{2)}$ \\ 1 Program Studi Ilmu Pemerintahan, Stisipol Raja Haji Tanjungpinang. Jalan Raja Haji Fisabilillah \\ Km.8 No.48, Kota Tanjungpinang, Kepulauan Riau, 29111 Indonesia. \\ 2 Program Studi Ilmu Pemerintahan, Stisipol Raja Haji Tanjungpinang. Jalan Raja Haji Fisabilillah \\ Km.8 No.48, Kota Tanjungpinang, Kepulauan Riau, 29111 Indonesia \\ * Korespondensi Penulis. E-mail: rendra_tanjungpinang@yahoo.co.id, Telp: +6281268660986
}

\begin{abstract}
Abstrak
Persoalan pendidikan berhubungan dengan bagaimana mencapai tujuan pendidikan nasional. Oleh karena itu pemerintah menetapkan banyak standar dalam rangka mencapai tujuan pendidikan nasional. Banyak kebijakan yang telah ditetapkan oleh pemerintah, namun masih mengundang tanda tanya standar pendidikan yang mampu dan berkualitas dalam rangka meningkatkan pendidikan di Indonesia. Penelitian ini akan menjelaskan dengan statistik deskriptif tentang pandangan masyarakat tentang kebijakan standar nasional pendidikan yang tertuang di dalam Peraturan Pemerintah No. 19 Tahun 2005 tentang Standar Nasional Pendidikan yang kemudian disempurnakan menjadi PP No. 32 Tahun 2013 dan kemudian disempurnakan kembali menjadi PP No. 15 Tahun 2015. Tujuan penelitian ini adalah mengungkap pandangan masyarakat sekaligus menjadi input bagi pemerintah terkait dengan standar nasional pendidikan yang selama ini digunakan penelitian ini menggunakan pendekatan kuantitatif. Hasil penelitian ini adalah data statistik deskriptif pandangan masyarakat Kota Tanjungpinang terkait kebijakan standar nasional pendidikan khususnya pada pendidikan dasar di Kota Tanjungpinang. Hasil penelitian ini diharapkan mampu menjadi rekomendasi bagi pemerintah khususnya dalam penerapan standar nasional pendidikan di pendidikan dasar.
\end{abstract}

Kata kunci: Pandangan Masyarakat, Kebijakan, Standar Pendidikan, Pendidikan Dasar

\section{PUBLIC PERCEPTION ON THE NATIONAL EDUCATION STANDARDS POLICY}

(Studies in Primary Education Level in Tanjungpinang)

\section{Abstract}

Education problems related to the issue of state goals is educating the nation. Therefore, the Government should establish a policy on optimal standard of education for its society. A wide variety of standard policy on education has been issued by the government. But whether the policy on the standard is believed to be the best solution to improve the quality of education in Indonesia. This study will explain in descriptive statistics related to public perceptions of the standard policy of national policies in education, especially in Tanjungpinang, and focused on primary education. The purpose of this study is to reveal the preferences of society as well as the input to the relevant government standards to be improved and enhanced by the government. This research is descriptive with quantitative approach. The results of this study are related statistical description of public perception of the policy of national education standards in Tanjungpinang, especially at the primary level. This research is expected to be recommendations for government policy related to national education standards in Tanjungpinang, especially at the primary level.

Keywords: Public Perception, Policy, Education Standard, Primary Education 
Jurnal Ilmu Pemerintahan, 2 (1), April 2017 - 62

Rendra Setyadiharja, M.IP dan Dr. Neng Suryanti Nengsih, M.Si

\section{PENDAHULUAN}

Pembukaan Undang-undang 1945 mengamanatkan bahwa pembentukan Pemerintah Negara Indonesia yaitu antara lain untuk mencerdaskan kehidupan bangsa. Untuk mewujudkan upaya tersebut, Undangundang Dasar 1945 pasal 31 ayat 3 yang menyatakan bahwa "Pemerintah mengusahakan dan menyelenggarakan satu sistem pendidikan nasional, yang meningkatkan keimanan dan ketakwaan serta akhlak mulia dalam rangka mencerdaskan kehidupan bangsa, yang diatur dengan undang-undang.

Perwujudan dari amanat Undangundang Dasar 1945 yaitu dengan diberlakukannya Undang-Undang Nomor 20 Tahun 2003 Tentang Sistem Pendidikan Nasional, yang merupakan produk UndangUndang pendidikan pertama pada awal abad ke-21. Undang-Undang ini menjadi dasar hukum untuk membangun pendidikan nasional dengan menerapkan prinsip demokrasi, desentralisasi dan otonomi pendidikan yang menjunjung tinggi hak asasi manusia. Sejak Proklamasi Kemerdekaan 17 Agustus 1945, Undang-Undang tentang sistem pendidikan nasional telah mengalami beberapa kali perubahan.

Pendidikan nasional, sebagai salah satu sektor pembangunan nasional dalam upaya untuk mencerdaskan kehidupan bangsa, mempunyai visi terwujudnya sistem pendidikan sebagai pranata sosial yang kuat dan berwibawa untuk memberdayakan semua warga Indonesia berkembang menjadi manusia yang berkualiatas sehingga mampu dan pro aktif menjawab tantangan zaman yang selalu berubah. Makna manusia yang berkualitas, menurut Undang-undang Nomor 20 Tahun 2003 tentang Sistem Pendidikan Nasional yaitu manusia terdidik yang beriman dan bertakwa terhadap Tuhan Yang Maha Esa, berakhlak mulia, sehat, berilmu, cakap, kreatif, mandiri, dan menjadi warga negara yang demokratis dan bertanggung jawab. Oleh karena itu pendidikan nasional harus berfungsi secara optimal sebagi wahana utama dalam pembangunan bangsa dan karakter.

Penyelenggaraan pendidikan sebagaimana yang diamanatkan dalam Undangundang Nomor 20 Tahun 2003 tentang Sistem Pendidikan Nasional diharapkan dapat mewujudkan proses perkembangan pribadi peserta didik sebagai generasi penerus bangsa di masa depan, yang diyakini akan menjadi faktor determinan bagi tumbuh kembangnya bangsa dan negara Indonesia sepanjang jaman.

Untuk mengukur standar nasional pendidikan, sesuai amanat Pasal 35 tentang Standar Nasional Pendidikan yang menuliskan bahwa standar nasional pendidikan yang terdiri dari standar isi, proses, kompetensi kelulusan, tenaga pendidikan dan kependidikan, sarana dan prasarana, pengelolaan dan pembiayaan dan penilaian pendidikan yang kemudian menjadi acuan pengembangan kurikulum, tenaga pendidikan, sarana dan prasarana, pengelolaan dan pembiayaan. Kemudian sebagai petunjuk pelaksaan untuk melakukan pengawasan dan pengukuran standar nasional pendidikan maka pemerintah telah mengeluarkan Peraturan Pemerintah No. 19 Tahun 2005 tentang Standar Nasional Pendidikan yang kemudian disempurnakan menjadi PP No. 32 Tahun 2013 dan kemudian disempurnakan kembali menjadi PP No. 15 Tahun 2015 yang menyatakan bahwa Standar Nasional Pendidikan merupakan kriteria minimal tentang sistem pendidikan di seluruh wilayah hukum NKRI.

Kurikulum merupakan salah satu unsur yang bisa memberikan kontribusi yang signifikan untuk mewujudkan proses berkembangnya kualitas potensi peserta didik. Jadi tidak dapat disangkal lagi bahwa kurikulum yang dikembangkan dengan berbasis pada kompetensi sangat diperlukan sebagai instrumen untuk mengarahkan peserta didik menjadi: 
1. Manusia berkualitas yang mampu dan proaktif menjawab tantangan zaman yang selalu berubah.

2. Manusia terdidik yang beriman dan bertakwa kepada Tuhan Yang Maha Esa, berakhlak mulia, sehat, berilmu, cakap, kreatif dan mandiri.

3. Warga negara yang demokratis dan bertanggung jawab. Pengembangan dan pelaksanaan kurikulum berbasis kompetensi merupakan salah satu strategi pembangunan pendidikn nasional sebagaiman yang diamanatkan pada Undang-undang Nomor 20 Tahun 2003 tentang Sistem Pendidikan Nasional.

Kurikulum sebagai standar pertama dalam pengembangan pendidikan yang di atur dalam sistem pendidikan di Indonesia telah mengalami perubahan sebanyak $10 \mathrm{kali}$. Berikut sejarah perkembangan kurikulim di Indonesia yang penulis sajikan dalam bentuk timeline untuk mempermudah dalam memahami sejarah perkembangan kurikulum dari masa kolonialisme yang berawal dari tahun 1947.

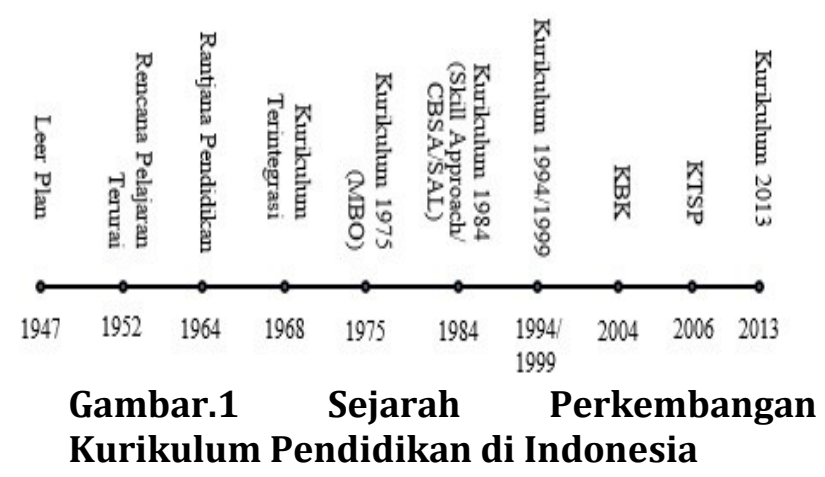

Dalam kurikulum 2013 ini, mata pelajaran berkontribusi pada semua ranah kompetensi dan keseragaman antara materi proses dan hasil. Perubahan kurikulum ini sedikit banyak memberi pengaruh terhadap siswa karena kurang siapnya siswa untuk beradaptasi dengan kurikulum yang baru, sehingga tidak menutup kemungkinan dapat menurunkan prestasi. Tujuan pemerintah mengganti kurikulum dalam pendidikan tidak lain karena ingin memperbaiki mutu pendidikan agar lebih berkembang dan mengikuti zaman, namun dalam penerapannya masih banyak kendala sehingga siswa tidak dapat menyesuaikan diri dengan sistem pembelajaran yang baru. Sehingga dalam pelaksanaan evaluasi atau ujian nasional siswa menggunakan segala cara untuk mendapatkan standar nilai kelulusan. Tidak hanya itu, bahkan beberapa sekolah memberikan bantuan kepada siswanya dengan cara sembunyi-sembunyi. Hal ini semakin memperburuk mental anak bangsa sebagai kader penerus di masa depan.

Dengan konsep kurikulum berbasis kompetensi, tak tepat jika ada yang menyampaikan bahwa pemerintah salah sasaran saat merencanakan perubahan kurikulum, karena yang perlu diperbaiki sebenarnya metodologi pembelajaran bukan kurikulum. Hal ini menunjukkan belum dipahaminya secara utuh bahwa kurikulum berbasis kompetensi termasuk mencakup metodologi pembelajaran.

Tanpa metodologi pembelajaran yang sesuai, tak akan terbentuk kompetensi yang diharapkan. Sebagai contoh, dalam Kurikulum 2013, kompetensi lulusan dalam ranah keterampilan untuk SD dirumuskan sebagai "memiliki (melalui mengamati, menanya, mencoba, mengolah, menyaji, menalar, mencipta) kemampuan pikir dan tindak yang produktif dan kreatif, dalam ranah konkret dan abstrak, sesuai dengan yang ditugaskan kepadanya." Kompetensi semacam ini tak akan tercapai bila pengertian kurikulum diartikan sempit, tak termasuk metodologi pembelajaran.

Bukan saja persoalan kurikulum, dimana standar pendidikan kedua yaitu berkaitan dengan tenaga pendidik dan tenaga kependidikan. Disisi ini akan lebih banyak berkaitan dengan kualitas guru dan tenaga kependidikan yang ada di sekolah. Guru merupakan aktor terdepan dalam pelaksanaan pendidikan yang berhadapan dengan 
peserta didik. Peran penting guru antara lain meliputi : kemampuan menjabarkan topiktopik bahasan pada mata pelajaran maenjadi informasi yang menarik dan mudah dipahami oleh peserta didik, kemampuasn mengidentifikasi tingkat dan area kesulitan peserta didik dan kemampuan untuk membantu keluar dari kesulitan tersebut dan kemampuan melakukan evaluasi kemajuan belajar siswa. Oleh karena itu bangsa Indonesia sangat membutuhkan kualitas guru yang mumpuni, bukan saja mampu mentransformasikan ilmu melainkan juga mampu memberikan nilai pendidikan bagi siswa.

Standar selanjutnya adalah standar sarana dan prasarana. Dalam hal ini Indonesia membutuhkan sebuah kondisi bangunan sekolah yang representatif dimana sekolah tidak lagi menjadi tempat yang menakutkan bagi siswa melainkan juga mampu menjadi rumah kedua bagi mereka. Tentunya akan berkaitan bagaimana dengan sarana dan prasarana di tempat siswa-siswa bersekolah. Kenyamanan lingkungan sekolah dari sisi gedung, laboratorium, perpustakaan yang lengkap, fasilitas olah raga dan tak boleh dilupakan juga sarana untuk meningkatkan bakat siswa seperti lapangan olah raga, ruang kesenian, dan lain sebagainya harusnya tersedia di sekolah agar siswa merasakan sebuah kenikmatan dan kenyamanan di lingkungan sekolah yang akan mampu mendukung meningkatkan suasana akademik di sekolah.

Selanjutnya adalah standar pembiayaan. Standar ini berkaitan dengan penyaluran Dana Operasional Sekolah (BOS) yang dikelola oleh sekolah dalam rangka membantu siswa dalam menjalani pendidikan dasar dan menengah. Penyaluran dana BOS ini haruslah menjunjung tinggi nilai transparansi, efektif dan efisien. Dana BOS haruslah menjadi sebuah asupan secara finansial untuk membantu siswa untuk menjalani pendidikannya, dan kita ketahui bahwa biaya pendidikan sekarang cukup tinggi oleh karena itu dana BOS haruslah bisa membantu siswa untuk menyelesaikan pendidikan dasar 9 tahunnya.

Standar terakhir adalah adalah standar pengelolaan. Dimana dalam hal ini berkaitan dengan Manajemen Berbasis Sekolah. Dimana dalam Manajemen Berbasis Sekolah ini haruslah melibatkan beberapa pihak dalam pengelolaan sekolah yaitu kepala sekolah, guru, tenaga pendidikan, orang tua siswa, masyarakat lingkungan sekolah. Dengan standar pengelolaan seperti ini, diharapkan sekolah tidak lagi menjadi aktor tunggal dalam rangka mendidik anak bangsa ini, namun akan lebih baik jika melibatkan pihakpihak tersebut dalam pengelolaan sekolah.

Kesemua standar tersebut diterapkan diseluruh wilayah Indonesia termasuk Kota Tanjungpinang. Terkadang muncul sebuah pertanyaan apakah kebijakan pengembangan pendidikan nasional dengan standar tersebut sudah efektif dalam rangka mengembangkan pendidikan di Indonesia terlebih khusunya di Kota Tanjungpinang. Apakah semua stakeholders baik itu guru, siswa dan masyrakat dalam hal ini mengetahui dengan jelas sehingga kebijakan pengembangan pendidikan ini dinilai efektif. Oleh karena itu, perlu dilakukan sebuah kajian mengenai efektivitas kebijakan pengembangan pendidikan nasional di Kota Tanjungpinang menurut masyarakat.

\section{METODE}

Untuk melihat objek penelitian agar lebih terinci dalam mengukur variabel dengan instrument yang telah disediakan penulis menggunakan metode survey dengan pendekatan kuantitatif. Adapun pendekatan penelitian kuantitafif yang digunakan dalam penelitian ini adalah dengan cara metode survey dengan menggunakan kuesioner sebagai alat pengumpulan data primer, sementara dokumentasi dan observasi sebagai alat dan teknik pengumpulan data sekunder. Penelitian ini menggunakan 120 sampel yang terdiri dari guru, masyarakat 
dan orang tua murid tingkat pendidikan dasar di 4 (empat) kecamatan di Kota Tanjungpinang, dengan teknik sampling menggunakan Random Sampling.

\section{HASIL DAN PEMBAHASAN}

\section{A. Konsep Kebijakan}

Kebijakan secara epistimologi, istilah kebijakan berasal dari bahasa Inggris "policy". Akan tetapi, kebanyakan orang berpandangan bahwa istilah kebijakan senantiasa disamakan dengan istilah kebijaksanaan. Padahal apabila dicermati berdasarkan tata bahasa, istilah kebijaksanaan berasal dari kata "wisdom".

Pendapat Anderson yang dikutip oleh Wahab, merumuskan kebijaksanaan sebagai langkah tindakan yang secara sengaja dilakukan oleh seseorang aktor atau sejumlah aktor berkenaan dengan adanya masalah atau persoalan tertentu yang sedang dihadapi (Anderson dalam Wahab, 2004:3). Oleh karena itu, kebijaksanaan menurut Anderson merupakan langkah tindakan yang sengaja dilakukan oleh aktor yang berkenaan dengan adanya masalah yang sedang di hadapi.

Kebijakan menurut pendapat Carl Friedrich yang dikutip oleh Wahab bahwa: "Kebijakan adalah suatu tindakan yang mengarah pada tujuan yang diusulkan oleh seseorang, kelompok atau pemerintah dalam lingkungan tertentu sehubungan dengan adanya hambatanhambatan tertentu

seraya mencari peluang-peluang untuk mencapai tujuan atau mewujudkan sasaran yang diinginkan" (Friedrich dalam Wahab, 2004:3).

Berdasarkan definisi di atas, kebijakan mengandung suatu unsur tindakan-tindakan untuk mencapai tujuan. Umumnya tujuan tersebut ingin dicapai oleh seseorang, kelompok ataupun pemerintah. Kebijakan tentu mempunyai hambatan-hambatan pada pelaksanaannya tetapi harus mencari peluang-peluang untuk mewujudkan tujuan yang diinginkan.
Kebijakan mengandung suatu unsur tindakan untuk mencapai tujuan dan umumnya tujuan tersebut ingin dicapai oleh seseorang, kelompok ataupun pemerintah. Kebijakan tentu mempunyai hambatanhambatan tetapi harus mencari peluangpeluang untuk mewujudkan tujuan dan sasaran yang diinginkan. Hal tersebut berarti kebijakan tidak boleh bertentangan dengan nilai-nilai dan pelaksanaan sosial yang ada dalam masyarakat. Apabila kebijakan berisi nilai-nilai yang bertentangan dengan nilainilai yang hidup dalam masyarakat, maka kebijakan tersebut akan mendapat kendala ketika di implementasikan. Sebaliknya, suatu kebijakan harus mampu mengakomodasikan nilai-nilai dan praktik-praktik yang hidup dan berkembang dalam masyarakat.

\section{B. Konsep Standar Nasional Pendidikan}

Peraturan Pemerintah No. 19 Tahun 2005 tentang Standar Nasional Pendidikan yang kemudian disempurnakan menjadi PP No. 32 Tahun 2013 dan kemudian disempurnakan kembali menjadi PP No. 15 Tahun 2015 serta berdasarkan paparan Menteri Pendidikan dan Kebudayaan Republik Indonesia (2013) bahwa pengembangan pendidikan nasional mengacu pada standar berikut.

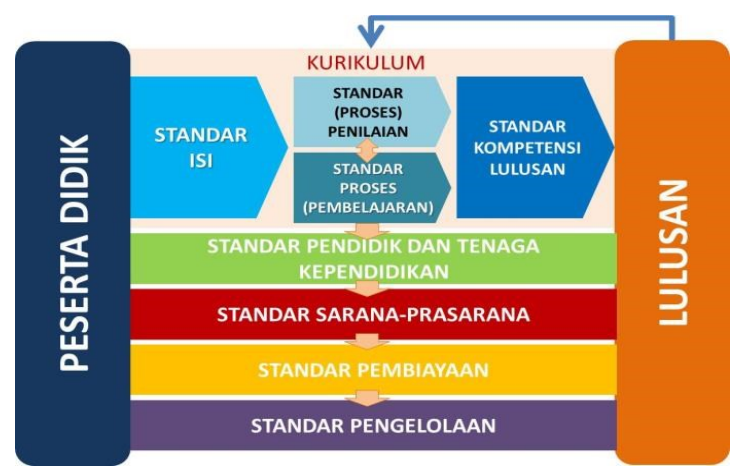

\section{Gambar.2 Standar Pengembangan Pendidikan Nasional}

Standar Nasional Pendidikan yang meliputi standar pengelolaan, standar biaya, standar sarana prasarana, standar pendidik dan tenaga kependidikan, standar isi, standar proses, standar penilaian, dan standar 
kompetensi lulusan. Tantangan internal lainnya terkait dengan faktor perkembangan penduduk Indonesia dilihat dari pertumbuhan penduduk usia produktif. Terkait dengan tantangan internal pertama, berbagai kegiatan dilaksanakan untuk mengupayakan agar penyelenggaraan pendidikan dapat mencapai ke delapan standar yang telah ditetapkan.

Pengembangan pendidikan mengacu pada 8 standar dengan dikelompokkan dalam 5 aspek yaitu :

\section{Aspek Kurikulum Pendidikan ,} dimana didalam kurikulum terdapat beberapa standar isi, standar (proses) penilaian, standar proses (pembelajaran) dan standar kompetisi lulusan yang diukur dengan hal-hal sebagai berikut.

\section{a. Standar Isi}

Standar ini diukur dengan hal-hal sebagai berikut.

1. Kurikulum yang digunakan dalam pendidikan dasar saat ini sudah sangat sesuai dan menjawab tantangan masa depan

2. Keterlibatan orang tua dan masyarakat secara luas sangat diperlukan dalam pengembangan kurikulum dalam pendidikan dasar

\section{b. Standar Proses Pembelajaran}

Standar ini diukur dengan hal-hal sebagai berikut.

1. Proses pembelajaran pada sekolah dasar seharusnya hanya terpusat pada guru.

2. Proses pembelajaran pada sekolah dasar sebaiknya terpusat pada siswa dengan banyaknya peran siswa dalam pembelajaran dan guru hanya sebagai fasilitator.

3. Ada keterlibatan peran orang tua siswa dalam merancang proses pembelajaran.

\section{c. Standar Proses Penilaian}

Standar ini diukur dengan hal-hal sebagai berikut.

1. Menilai kemampuan siswa pada pendidikan dasar hanya dilihat dari hasil pembelajaran siswa.

2. Menilai kemampuan siswa pada pendidikan dasar hanya dilihat dari kerajinan dan perilaku siswa.

3. Menilai kemampuan siswa pada pendidikan dasar merupakan gabugan antara nilai pembelajaran, kerajinan, dan perilaku siswa.

\section{d. Standar Lulusan}

Standar ini diukur dengan hal-hal sebagai berikut.

1. Sistem kelulusan tingkat pendidikan dasar sekarang ini terlalu kaku dengan hanya melihat nilai akhir berdasarkan sisi pengetahuan belaka tanpa mempertimbangkan sisi sikap dan perilaku siswa.

2. Hasil lulusan sekolah pada jenjang pendidikan dasar saat ini sudah mampu mencerminkan kualitas pendidikan dasar di Indonesia

II. Aspek Tenaga Pendidik dan Tenaga Kependidikan, dimana didalam aspek ini terdapat hal yang penting seperti peningkatan kualifikasi dan sertifikasi, pembayaran tunjangan sertifikasi, dan uji kompetensi dan pengukuran kenirja.

Standar ini diukur dengan hal-hal sebagai berikut.

1. Kualitas guru pada pendidikan dasar saat ini sudah dapat dikatakan berkompeten dalam mengelola pendidikan.

2. Kuantitas atau jumlah guru pada suatu sekolah dasar saat ini sudah dinilai cukup dan memadai

3. Untuk menciptakan suatu kualitas pendidikan dasar yang sempurna harus ada keterlibatan antara 
pemerintah, sekolah, orang tua dan masyarakat.

III. Aspek Sarana dan Prasarana, dimana didalam aspek ini terdapat beberapa hal penting yang berupa Rehab Gedung Sekolah, Penyediaan Lab dan Perpustakaan,dan Penyediaan Buku.

Standar ini diukur dengan hal-hal sebagai berikut.

a. Sarana dan prasarana sekolah pada jenjang pendidikan dasar selama ini sudah mampu mendukung sistem pembelajaran siswa di sekolah.

b. Keterlibatan orang tua dan masyarakat sangat diperlukan dalam pemenuhan dan pemeliharaan sarana dan prasarana di sekolah selain tanggung jawab sekolah dan pemerintah

c. Keterlibatan orang tua dan masyarakat sangat diperlukan dalam memenuhi kebutuhan buku siswa dan perpustakaan sekolah selain tanggung jawab sekolah dan pemerintah.

IV. Aspek Pembiayaan, dimana didalam aspek ini terdapat hal yang berkaitan dalam aspek pembiayaan BOS, Bantuan Siswa Miskin dan BOPTN/Bidik Misi (di PT).

Standar ini diukur dengan hal-hal sebagai berikut.

a. Sekolah saat ini telah melakukan standar pembiayaan yang baik, transparan dan akuntabel.

b. Sekolah pada jenjang pendidikan dasar telah berhasil mengelola dan Bantuan Operasional Sekolah dengan baik dan transparan serta akuntabel sehingga memudahkan siswa dalam menjalani pendidikan.

c. Keterlibatan orang tua dan masyarakat luas sangat diperlukan dalam pengawasan dan audit keuangan di sekolah termasuk dana BOS.

d. Dalam pelaksanaannya Dana BOS telah tepat pada sasarannya sehingga saat membantu kelompok sasaran tersebutt dalam menjalani pendidikan dasar.

V. Aspek Pengelolaan, didalam aspek ini bagaimana mengatur manajemen berbasis sekolah sehingga tercipta sekolah yang mampu menciptakan SDM yang baik.

Standar ini diukur dengan hal-hal sebagai berikut.

a. Sekolah telah mampu mengelola dan mengembangkan pendidikan dasar dengan baik.

b. Melibatkan orang tua dan masyarakat dalam perencanaan, pelaksanaan, dan evaluasi pengelolaan sekolah pada jenjang pendidikan dasar adalah sangat diperlukan.

\section{Pandangan Masyarakat Terhadap Kebijakan Standar Nasional Pendidikan Di Kota Tanjungpinang}

I. Aspek Kurikulum Pendidikan

a. Standar Isi Kurikulum

Sesuai Standar Nasional Pendidikan yang ditetapkan Pemerintah dalam No. 19 Tahun 2005 tentang Standar Nasional Pendidikan yang kemudian disempurnakan menjadi PP No. 32 Tahun 2013 dan kemudian disempurnakan kembali menjadi PP No. 15 Tahun 2015 yang menyatakan bahwa Standar Nasional Pendidikan maka aspek pertama yang akan diukur adalah aspek kurikulum pendidikan. Dalam kurikulum ini terdapat beberapa dimensi yang akan diukur yaitu Standar isi kurikulum, Standar Pembelajaran, Standar Proses Penilaian, dan Standar Kelulusan.

Dimensi standar isi kurikulum terdapat pula beberapa hal yang menjadi indikator penelitian yaitu kurikulum yang digunakan dalam pendidikan dasar saat ini sudah sangat sesuai dan menjawab tantangan masa depan, 
Jurnal Ilmu Pemerintahan, 2 (1), April 2017 - 68

Rendra Setyadiharja, M.IP dan Dr. Neng Suryanti Nengsih, M.Si

dan Keterlibatan orang tua dan masyarakat secara luas sangat diperlukan dalam pengembangan kurikulum dalam pendidikan dasar.

Berdasarkan hasil penelitian yang telah dilakukan maka pengukuran indikator utama diperoleh data sebagaimana dijelaskan pada tabel berikut.

Tabel 1. Kurikulum Yang Digunakan Dalam Pendidikan Dasar Saat Ini Sudah Sangat Sesuai Dan Menjawab Tantangan Masa Depan Bangsa

\begin{tabular}{lcc}
\hline $\begin{array}{c}\text { Kurikulum sesuai } \\
\text { dengan tantangan } \\
\text { masa depan }\end{array}$ & JUMLAH & PERSENTASE \\
SANGAT SETUJU & 17 & $14 \%$ \\
SETUJU & 79 & $66 \%$ \\
KURANG SETUJU & 22 & $18 \%$ \\
TIDAK SETUJU & 2 & $2 \%$ \\
TIDAK TAHU & 0 & $0 \%$ \\
TOTAL & $\mathbf{1 2 0}$ & $\mathbf{1 0 0 \%}$ \\
\hline SUT & & \\
\hline
\end{tabular}

Sumber: Data Olahan, 2015

Berdasarkan Tabel 1 menyatakan bahwa 80\% responden Sangat Setuju dan Setuju, bahwa kurikulum yang digunakan dalam pendidikan dasar saat ini sudah sangat sesuai dan menjawab tantangan masa depan bangsa. Hanya $20 \%$ yang menyatakan pandangan negatif yaitu kurang setuju dan tidak setuju. Itu artinya Kurikulum KTSP yang digunakan dalam jenjang pendidikan dasar saat ini dinilai masyarakat sesuai dengan tantangan yang akan dihadapi siswa di masa yang akan datang. Kesesuaian materi ajar yang diberikan oleh guru kepada siswa saat relevan dengan kondisi zaman dan masa depan yang nantinya akan ditemui oleh siswa ketika ia akan beranjak ke jenjang pendidikan yang lebih tinggi.

Selanjutnya indikator kedua dari standar isi kurikulum adalah sebagaimana dijelaskan pada tabel berikut ini.

Tabel 2. Keterlibatan Orang Tua Dan Masyarakat Secara Luas Sangat Diperlukan Dalam

Pengembangan Kurikulum Dalam Pendidikan

\begin{tabular}{lcc} 
& Dasar \\
\hline $\begin{array}{c}\text { Keterlibatan orang tua } \\
\text { dan masyarakat secara } \\
\text { luas sangat diperlukan } \\
\text { dalam pengembangan } \\
\text { kurikulum dalam }\end{array}$ & JUMLAH & PERSENTASE \\
$\quad$ pendidikan dasar & & \\
SANGAT SETUJU & 75 & $63 \%$ \\
SETUJU & 41 & $34 \%$ \\
KURANG SETUJU & 3 & $3 \%$ \\
TIDAK SETUJU & - & $0 \%$ \\
\hline
\end{tabular}

\begin{tabular}{lcc} 
TIDAK TAHU & 1 & $1 \%$ \\
TOTAL & $\mathbf{1 2 0}$ & $\mathbf{1 0 0 \%}$ \\
\hline
\end{tabular}

Sumber: Data Olahan, 2015

Berdasarkan tabel di atas, dapat ditunjukkan bahwa $58 \%$ responden menyatakan sangat setuju dan setuju terhadap indikator keterlibatan orang tua dan masyarakat secara luas dalam pengembangan kurikulum pada tingkat pendidikan dasar, dan hanya 29\% yang menyatakan tidak setuju dan $13 \%$ yang menyatakan tidak tahu. Itu artinya responden berpendapat bahwa keterlibatan orang tua dan masyaraka sangat dibutuhkan dalam pengembangan dalam pendidikan dasar.

\section{b. Standar Proses Pembelajaran}

Standar selanjutnya dalam aspek kurikulum adalah standar proses pembelajaran. Di dalam standar ini hal-hal yang menjadi penilaian dan akan diambil sebuah pandangan dari masyarakat adalah terkait indikator berikut yaitu, proses pembelajaran pada sekolah dasar seharusnya hanya terpusat pada guru, proses pembelajaran pada sekolah dasar sebaiknya terpusat pada siswa dengan banyaknya peran siswa dalam pembelajaran dan guru hanya sebagai fasilitator, dan adanya keterlibatan peran orang tua siswa dalam merancang proses pembelajaran.

Maka dari beberapa indikator tersebut, diperoleh hasil masing-masing indikator sebagai berikut.

Tabel 3. Proses Pembelajaran Pada Sekolah Dasar Seharusnya Hanya Terpusat Pada Guru

\begin{tabular}{lcc}
\hline $\begin{array}{c}\text { Proses pembelajaran } \\
\text { pada sekolah dasar } \\
\text { seharusnya hanya } \\
\text { terpusat pada guru }\end{array}$ & JUMLAH & PERSENTASE \\
SANGAT SETUJU & 7 & $6 \%$ \\
SETUJU & 24 & $20 \%$ \\
KURANG SETUJU & 33 & $28 \%$ \\
TIDAK SETUJU & 53 & $44 \%$ \\
TIDAK TAHU & 3 & $3 \%$ \\
TOTAL & $\mathbf{1 2 0}$ & $\mathbf{1 0 0 \%}$ \\
\hline Sumbe: Data Olahan, 2015 & &
\end{tabular}

Sumbe: Data Olahan, 2015

Berdasarkan data yang diperllihatkan pada tabel di atas, maka diperoleh data bahwa terdapat 58\% responden menyatakan sangat setuju dan setuju bahwa proses 
pembelajaran pada sekolah seharusnya hanya terpusat pada guru. Namun juga terdapat 29\% responden yang tidak setuju bahwa proses pembelajaran pada sekolah seharusnya terpusat pada guru, dan 13\% tidak tahu dalam menjawab penyataan tersebut. Itu artinya sebagian besar responden berpandangan sepakat, bahwa dalam proses pembelajaran peran guru masih sangat mempengaruhi dan sangat menentukan.

Kemudian indikator selanjutnya yang dilakukan pengukuran adalah terkait dengan proses pembelajaran pada sekolah dasar sebaiknya terpusat pada siswa dengan banyaknya peran siswa dalam pembelajaran dan guru hanya sebagai fasilitator. Berdasarkan hasil penelitian maka diperoleh data sebagai berikut.

Tabel 4. Proses Pembelajaran Pada Sekolah Dasar Sebaiknya Terpusat Pada Siswa Dengan Banyaknya Peran Siswa Dalam Pembelajaran Dan Guru Hanya Sebagai Fasilitator

\begin{tabular}{|c|c|c|}
\hline $\begin{array}{c}\text { Proses pembelajaran } \\
\text { pada sekolah dasar } \\
\text { sebaiknya terpusat } \\
\text { pada siswa dengan } \\
\text { banyaknya peran } \\
\text { siswa dalam } \\
\text { pembelajaran dan } \\
\text { guru hanya sebagai } \\
\text { fasilitator }\end{array}$ & JUMLAH & PERSENTASE \\
\hline SANGAT SETUJU & 25 & $21 \%$ \\
\hline SETUJU & 46 & $38 \%$ \\
\hline KURANG SETUJU & 26 & $22 \%$ \\
\hline TIDAK SETUJU & 22 & $18 \%$ \\
\hline TIDAK TAHU & 1 & $1 \%$ \\
\hline TOTAL & 120 & $100 \%$ \\
\hline
\end{tabular}

Sumber: Data Olahan, 2015

Berdasarkan data di atas, tampak bawah pandangan masyarakat lebih beragam, dilihat dari dekatnya perbedaan persentase masing-masing jawaban, tampak 38\% responden mendominasi menjawab setuju jika proses pembelajaran pada sekolah dasar sebaiknya terpusat pada siswa dengan banyaknya peran siswa dalam pembelajaran dan guru hanya sebagai fasilitator, namun terdapat 22\% yang kurang setuju dan 21\% yang sangat setuju. Namun jika dianalisis lebih lanjut dari angka ini, maka sekitar 59\% yang menjawab sangat setuju dan setuju, dan hanya $41 \%$ yang menjawab dengan kecenderungan negatif yaitu kurang setuju, tidak setuju atau bahkan tidak tahu. Artinya pandangan masyarakat cenderung positif dengan penyataan pada indikator ini.

Indikator selanjutnya masih dalam indikator proses pembelajaran yaitu adanya keterlibatan peran orang tua siswa dalam merancang proses pembelajaran. Hasil dari pengukuran indikator ini sebagaimana dipaparkan pada tabel berikut.

Tabel 5. Adanya Keterlibatan Peran Orang Tua Siswa Dalam Merancang Proses Pembelajaran

\begin{tabular}{lcc}
\hline $\begin{array}{c}\text { Ada keterlibatan peran } \\
\text { orang tua siswa dalam } \\
\text { merancang proses } \\
\text { pembelajaran }\end{array}$ & JUMLAH & PERSENTASE \\
SANGAT SETUJU & 31 & $26 \%$ \\
SETUJU & 52 & $43 \%$ \\
KURANG SETUJU & 8 & $7 \%$ \\
TIDAK SETUJU & 26 & $22 \%$ \\
TIDAK TAHU & 3 & $3 \%$ \\
TOTAL & $\mathbf{1 2 0}$ & $\mathbf{1 0 0 \%}$ \\
\hline
\end{tabular}

Sumber: Data Olahan, 2015

Berdasarkan data di atas, tampak 69\% responden menjawab sangat setuju dan setuju, jika dalam menentukan proses pembelajaran, maka diperlukannya keterlibatan orang tua siswa dalam merancang proses pembelajaran. Sementara persentase jawaban negatif hanya 32\% yang menjawab dengan kecenderungan negatif dengan penyataan kurang setuju, tidak setuju jika adanya keterlibatan orang tua siswa dalam merancang proses pembelajaran.

\section{c. Standar Proses Penilaian}

Aspek kurikulum selanjutnya yang perlu dianalisis adalah standar proses penilaian, yang merupakan output dari kurikulum tersebut setelah diajarkan kepada peserta didik. Di dalam standar ini yang menjadi indikatornya adalah menilai kemampuan siswa pada pendidikan dasar hanya dilihat dari hasil pembelajaran siswa, menilai kemampuan siswa pada pendidikan dasar hanya dilihat dari kerajinan dan perilaku siswa, dan menilai kemampuan siswa pada 
Jurnal Ilmu Pemerintahan, 2 (1), April 2017 - 70

Rendra Setyadiharja, M.IP dan Dr. Neng Suryanti Nengsih, M.Si

pendidikan dasar merupakan gabugan antara nilai pembelajaran, kerajinan, dan perilaku siswa. Tampak dari beberapa indikator ini nantinya akan dilihat bagaimana tanggapan masyarakat dengan bagaimana sebenarnya proses penilaian yang layak bagi peserta didik.

Indikator pertama yaitu menilai kemampuan siswa pada pendidikan dasar hanya dilihat dari hasil pembelajaran siswa. Data hasil penelitian memperlihatkan data sebagai berikut.

Tabel 6. Menilai Kemampuan Siswa Pada Pendidikan Dasar Hanya Dilihat Dari Hasil Pembelajaran Siswa

\begin{tabular}{lcc}
\hline $\begin{array}{c}\text { Menilai kemampuan } \\
\text { siswa pada pendidikan } \\
\text { dasar hanya dilihat dari } \\
\text { hasil pembelajaran siswa }\end{array}$ & JUMLAH & PERSENTASE \\
SANGAT SETUJU & 6 & \\
SETUJU & 25 & $5 \%$ \\
KURANG SETUJU & 48 & $21 \%$ \\
TIDAK SETUJU & 40 & $40 \%$ \\
TIDAK TAHU & 1 & $33 \%$ \\
TOTAL & $\mathbf{1 2 0}$ & $1 \%$ \\
\hline Sumber: Data Olahan, 2015 & & $\mathbf{1 0 0 \%}$ \\
\hline
\end{tabular}

Berdasarkan hasil olahan data di atas, maka dapat disimpulkan bahwa ternyata sebanyak $74 \%$ masyarakat cenderung memberikan tanggapan negatif atas penyataan indikator ini, hanya $26 \%$ yang kecenderungan jawaban responden menjawab sangat setuju dan setuju. Itu artinya masyarakat tidak sepakat bahwa proses penilaian hanya didasarkan atas hasil pembelajaran siswa semata.

Indikator selanjutnya memperlihatkan sebuah penyataan yang lebih berbeda dari indikator pertama yaitu menilai kemampuan siswa pada pendidikan dasar hanya dilihat dari kerajinan dan perilaku siswa. Hasil olahan data yang dilakukan dalam penelitian ini menghasilkan data sebagai berikut.

Tabel 7. Menilai Kemampuan Siswa Pada Pendidikan Dasar Hanya Dilihat Dari Kerajinan Dan Perilaku Siswa

\begin{tabular}{lcc}
\hline $\begin{array}{c}\text { Menilai kemampuan } \\
\text { siswa pada pendidikan } \\
\text { dasar hanya dilihat dari } \\
\text { kerajinan dan perilaku } \\
\quad \text { siswa }\end{array}$ & JUMLAH & PERSENTASE \\
SANGAT SETUJU & & \\
SETUJU & 9 & $8 \%$ \\
KURANG SETUJU & 24 & $20 \%$ \\
\hline
\end{tabular}

\begin{tabular}{lcc}
\hline TIDAK SETUJU & 39 & $33 \%$ \\
TIDAK TAHU & 2 & $2 \%$ \\
TOTAL & $\mathbf{1 2 0}$ & $\mathbf{1 0 0 \%}$ \\
\hline
\end{tabular}

Sumber: Data Olahan, 2015

Data ini juga menunjukkan bahwa sekitar 73\% responden menjawab dengen kecenderungan negatif yaitu kurang setuju dan tidak setuju dan tidak tahu, dan hanya 28\% responden menjawab positif terhadap pernyataan pada indikator ini. Itu artinya, masyarakat berpandangan tidak sepakat jika para guru atau pendidik atau amanat kurikulum, menilai kemampuan siswa hanya pada aspek kerajinan dan perilaku siswa. Karena sudut pandangan masyarakat tidak hanya aspek ini yang menjadi penilaian. Namun juga pada aspek ilmu pengetahuan juga, namun tidak hanya juga pada aspek ilmu pengetahuan dalam aspek pembelajaran namun penilaian harus lebih komprehensif.

Indikator selanjutnya yang dilakukan penilaian adalah menilai kemampuan siswa pada pendidikan dasar merupakan gabugan antara nilai pembelajaran, kerajinan, dan perilaku siswa. Data olahan penelitian memperlihatkan data sebagai berikut.

Tabel 8. Menilai Kemampuan Siswa Pada Pendidikan Dasar Merupakan Gabugan Antara Nilai

Pembelajaran, Kerajinan, dan Perilaku Siswa

Menilai kemampuan

siswa pada

pendidikan dasar

merupakan gabungan antara nilai

JUMLAH PERSENTASE pembelajaran, kerajinan dan perilaku siswa

SANGAT SETUJU

SETUJU

KURANG SETUJU

TIDAK SETUJU

TIDAK TAHU

TOTAL

Sumber: Data Olahan, 2015

$\begin{array}{cc}63 & 53 \% \\ 56 & 47 \% \\ 1 & 1 \% \\ - & 0 \% \\ - & 0 \% \\ \mathbf{1 2 0} & \mathbf{1 0 0} \%\end{array}$

Berdasarkan data di atas, maka dapat disimpulkan bahwa sebanyak 99\% responde menjawab sangat setuju dan setuju jika siswa memang dinilai dari gabungan antara nilai pembelajaran, kerajian dan juga perilaku siswa. Hanya $1 \%$ responden yang menjawab tidak setuju.

Dari ketiga indikator tersebut, maka dapat diketahui bahwa masyarakat ber- 
Jurnal Ilmu Pemerintahan, 2 (1), April 2017 - 71

Rendra Setyadiharja, M.IP dan Dr. Neng Suryanti Nengsih, M.Si

pandangan bahwa aspek penilaian siswa tidak hanya pada tataran aspek kognitif (pengetahuan) namun siswa juga harus dinilai dari sisi afektif (pemahaman) dan juga psikomotorik. Dengan komprehensifnya metode penilaian, maka siswa dapat belajar sesuai modalitas belajarnya dimana siswa biasanya memiliki modalitas belajar visual, audio, kinestetik, ataupun gabungan beberapa modalitas belajar tersebut. Para pendidikan seyogyanya mengetahui akan hal tersebut. Ujian Nasional yang merupakan muara kelulusan siswa dianggap bertentangan dengan pandangan ini karena siswa hanya dinilai dari sisi proses pembelajaran semata. Sehingga Ujian Nasional perlu kiranya mendapatkan evaluasi dan peninjauan ulang apakah layak sebagai instrumen akhir dari sebuah proses pembelajaran yang telah dilalui siswa dalam waktu yang lama di jenjang pendidikan tingkat dasar.

\section{d. Standar Lulusan}

Standar terakhir dalam mengukur aspek kurikulum adalah standar lulusan. Standar ini diukur dengan dua indikator yaitu pertama, sistem kelulusan tingkat pendidikan dasar sekarang ini terlalu kaku dengan hanya melihat nilai akhir berdasarkan sisi pengetahuan belaka tanpa mempertimbangkan sisi sikap dan perilaku siswa, kedua, Hasil lulusan sekolah pada jenjang pendidikan dasar saat ini sudah mampu mencerminkan kualitas pendidikan dasar di Indonesia.

Berdasarkan hasil penelitian yang telah dilakukan maka pada indikator pertama diperoleh hasil sebagai berikut.
Tabel 9. Sistem Kelulusan Tingkat Pendidikan Dasar Sekarang Ini Terlalu Kaku Dengan Hanya Melihat Nilai Akhir Berdasarkan Sisi Pengetahuan Belaka Tanpa Mempertimbangkan Sisi Sikap Dan Perilaku Siswa

\begin{tabular}{lcc}
$\begin{array}{c}\text { Sistem kelulusan } \\
\text { tingkat pendidikan } \\
\text { dasar terlalu kaku }\end{array}$ & JUMLAH & PERSENTASE \\
SANGAT SETUJU & 23 & $19 \%$ \\
SETUJU & 44 & $37 \%$ \\
KURANG SETUJU & 24 & $20 \%$ \\
TIDAK SETUJU & 29 & $24 \%$ \\
TIDAK TAHU & - & $0 \%$ \\
TOTAL & $\mathbf{1 2 0}$ & $\mathbf{1 0 0 \%}$ \\
\hline
\end{tabular}

Sumber: Data Olahan, 2015

Berdasarkan data di atas, maka diperoleh data bahwa 56\% responden menyatakan sangat setuju dan setuju bahwa sistem kelulusan tingkat pendidikan dasar ini terlalu kaku dengan hanya melihat nilai akhir berdasarkan sisi pengetahuan belaka tanpa mempertimbangankan sisi sikap dan perilaku siswa. Hanya 44\% yang menyatakan tidak setuju atas penyataan ini. Kelulusan sekolah dasar dengan instrumen Ujian Nasional Berstandar Nasional (UASBN) pada akhirnya hanya mempertaruhkan nama baik sekolah meraih tingkat kelulusan terbaik dari sisi nilai.

Selanjutnya setelah dilakukan pengukuran terhadap indikator kedua dimensi ini, maka diperoleh data sebagai berikut.

Tabel 10. Hasil Lulusan Sekolah Pada Jenjang Pendidikan Dasar Saat Ini Sudah Mampu Mencerminkan Kualitas Pendidikan Dasar di Indonesia

\begin{tabular}{lcc}
\hline $\begin{array}{c}\text { Hasil lulusan sekolah } \\
\text { pada jenjang } \\
\text { pendidikan dasar }\end{array}$ & & \\
$\begin{array}{c}\text { saat ini sudah mampu } \\
\text { mencerminkan } \\
\text { kualitas pendidikan } \\
\text { dasar di Indonesia }\end{array}$ & JUMLAH & PERSENTASE \\
SANGAT SETUJU & 15 & \\
SETUJU & 65 & $13 \%$ \\
KURANG SETUJU & 26 & $22 \%$ \\
TIDAK SETUJU & 4 & $3 \%$ \\
TIDAK TAHU & 10 & $8 \%$ \\
TOTAL & $\mathbf{1 2 0}$ & $\mathbf{1 0 0} \%$ \\
\hline
\end{tabular}

Sumber: Data Olahan, 2015

Berdasarkan data di atas, tampak bahwa sebanyak $67 \%$ responden 
Jurnal Ilmu Pemerintahan, 2 (1), April 2017 - 72

Rendra Setyadiharja, M.IP dan Dr. Neng Suryanti Nengsih, M.Si

menyatakan sangat setuju dan setuju atas penyataan pada indikator ini, dan hanya 33\% yang menyatakan responden yang negatif yaitu tidak setuju, kurang setuju dan tidak tahu. Itu artinya, meski dalam indikator sebelumnya menyatakan bahwa kelulusan masih didominasi peran nilai akhir sebagai instrumen, namun masyarakat sepakat bahwa hasil lulusan sekolah pada jenjang pendidikan dasar saat ini sudah mampu mencerminkan kualitas pendidikan dasar di Indonesia. Salah satu cerminan yang tampak dari lulusan pendidikan tingkat dasar adalah kemahiran dalam membaca dan berhitung. Tampaknya kemampuan dasar ini masih mendominasi lulusan pendidikan dasar untuk mereka beranjak ke jenjang berikutnya.

\section{Aspek Tenaga Pendidik Dan Tenaga Kependidikan}

Dalam aspek tenaga pendidik dan tenaga kependidikan, maka ada beberapa hal yang menjadi indikator yang menjadi pengukuran, pertama, persepsi masyarakat terhadap kualitas guru pada pendidikan dasar, kedua, adalah persepsi masyarakat terhadap kuantitas guru di pendidikan dasar dan ketiga, persepsi masyarakat terhadap pelibatan pemerintah, sekolah, orang tua, dan masyarakat dalam menciptakan pendidikan berkualitas.

Berdasarkan hasil penelitian indikator pertama yaitu persepsi masyarakat terhadap kualitas guru pada pendidikan dasar, maka diperoleh data sebagai berikut.

Tabel 11. Persepsi Masyarakat Terhadap Kualitas Guru Pada Pendidikan Dasar

\begin{tabular}{ccc}
\hline $\begin{array}{c}\text { Kualitas guru pada } \\
\text { pendidikan dasar } \\
\text { saat ini sudah dapat } \\
\begin{array}{c}\text { dikatakan } \\
\text { berkompeten dalam } \\
\text { mengelola }\end{array}\end{array}$ & JUMLAH & PERSENTASE \\
$\begin{array}{c}\text { pendidikan } \\
\text { SANGAT SETUJU }\end{array}$ & 16 & \\
SETUJU & 65 & $13 \%$ \\
KURANG SETUJU & 18 & $15 \%$ \\
\hline
\end{tabular}

\begin{tabular}{lcc}
\hline TIDAK SETUJU & 11 & $9 \%$ \\
TIDAK TAHU & 10 & $8 \%$ \\
TOTAL & $\mathbf{1 2 0}$ & $\mathbf{1 0 0 \%}$ \\
\hline
\end{tabular}

Sumber: Data Olahan, 2015

Berdasarkan tabel di atas, maka diperoleh data bahwa sebanyak 69\% masyarakat menyatakan sangat setuju dan setuju bahwa kualitas guru pada pendidikan dasar khususnya di Kota Tanjungpinang dapat dinilai memiliki kompeten dalam mengelola pendidikan. Sementara hanya 32\% yang menyatakan kuran setuju, tidak setuju dan tidak tahu. Masyarakat berpandangan kompetensi guru pada jenjang pendidikan dasar di Kota Tanjungpinang sudah dinilai memiliki kompetensinya dalam mendidik siswa, baik kompetensi secara akademik yang dibuktikan dengan ijazah keguruan, kemudain kompetensi pegadodik yang berperan dalam proses pembelajaran dan juga kompetensi emosial yang baik dalam mendidik. Pandangan masyarakat ini mengisyaratkan kepercayaan masyarakat terhadap kualitas para pendidik di Kota Tanjungpinang. Hasil pengukuran terhadap indikator kedua dihasilkan data sebagai berikut.

Tabel 12. Persepsi Masyarakat Terhadap Kuantitas Guru Di Pendidikan Dasar

\begin{tabular}{lcc}
\hline $\begin{array}{c}\text { Kuantitas atau } \\
\text { jumlah guru pada } \\
\text { suatu sekolah dasar } \\
\text { saat ini sudah dinilai } \\
\text { cukup dan memadai }\end{array}$ & JUMLAH & PERSENTASE \\
SANGAT SETUJU & 10 & \\
SETUJU & 63 & $53 \%$ \\
KURANG SETUJU & 34 & $28 \%$ \\
TIDAK SETUJU & 12 & $10 \%$ \\
TIDAK TAHU & 1 & $1 \%$ \\
TOTAL & $\mathbf{1 2 0}$ & $\mathbf{1 0 0} \%$ \\
\hline
\end{tabular}

Sumber: Data Olahan, 2015

Berdasarkan data di atas, dapat disimpulkan bahwa $61 \%$ menyatakan sangat setuju dan setuju bahwa kuantitas atau jumlah guru pada suatu sekolah dasar saat ini sudah dinilai cukup dan memadai, dan 39\% masyarakat menyatakan kurang setuju, tidak setuju dan tidak tahu. Itu artinya bahwa masyakat Kota Tanjungpinang masih menyatakan bahwa kuantitas guru atau 
jumlah guru di Kota Tanjungpinang masih dinilai cukup dan memadai dengan jumlah peserta didik di tingkat sekolah dasar.

Indikator lainnya yang menjadi pengukuran yaitu persepsi masyarakat terhadap pelibatan pemerintah, sekolah, orang tua, dan masyarakat dalam menciptakan pendidikan berkualitas. Berdasarkan hasil penelitian maka diperoleh data sebagai berikut.

$\begin{aligned} & \text { Tabel 13. Persepsi Masyarakat Terhadap Pelibatan } \\ & \text { Pemerintah, Sekolah, Orang Tua, dan Masyarakat } \\ & \text { Dalam Menciptakan Pendidikan Berkualitas }\end{aligned}$
$\begin{aligned} & \text { Untuk menciptakan } \\ & \text { suatu kualitas } \\ & \text { pendidikan dasar } \\ & \text { yang sempurna } \\ & \quad \text { harus ada }\end{aligned}$
$\begin{gathered}\text { keterlibatan antara } \\ \text { pemerintah, }\end{gathered}$

Sumber: Olahan Data, 2015

Berdasarkan data di atas, maka dapat diperoleh data bahwa 98\% masyarakat menyatakan sangat setuju dan setuju bahwa dalam menciptakan kualitas pendidikan yang berkualitash harus terjadi pelibatan pemerintah, sekolah, orang tua, dan masyarakat, dan hanya $2 \%$ yang menyatakan pandangan dalam konteks negatif. Hal ini bermaksud bahwa tenaga pendidik yaitu guru harus selalu diawasi dan dibina terus menerus sepenuhnya oleh pemerintah. Pemerintah dalam konteks ini adalah Dinas Pendidikan khususnya Dinas Pendidikan Kota Tanjungpinang. Pemerintah harus mengawasi dalam hal kompetensi pendidikan guru, kompeteni pedagogik guru dalam pembelajaran, kompetensi dan kemampuan guru dalam mengajar, terlebih lagi saat ini sistem pembelajaran sudah menggunakan sistem student centre learning dimana peran siswa dalam proses pembelajaran menjadi lebih dominan dari metode pembelajaran konvensional yang digunakan sebelumnya. Pengawas sekolah yang ditunjuk harus menjalankan tugas pokok dan fungsinya dengan tepat sehingga proses pengawaan berjalan selain pengawasan secara internal di sekolah. Selain itu masyarakat selaku user harus bekerjasama dalam mendidik putera puterinya di lingkungan keluarga. Dukungan terhadap proses pembelajaran yang diberikan oleh guru selama itu masih dalam tataran aturan yang baik dan tidak mengintimidasi anak, maka orang tua perlu mendukung dan turut menjalin komunikasi yang baik terhadap guru dan mendidik anak dengan intens jika anak berada di lingkungan keluarganya.

\section{Aspek Sarana Dan Prasarana}

Dalam aspek sarana dan prasarana ada beberapa hal yang menjadi variabel pengukuran untuk menjaring pendapat masyarakat tentang standar pendidikan yaitu, pertama, keterdukungan sarana dan prasarana terhadap sistem pembelajaran, kedua, Keterlibatan orang tua dan masyarakat dalam pemenuhan dan pemeliharaan sarana dan prasarana, dan ketiga, keterlibatan orang tua dan masyarakat dalam pemenuhan buku siswa dan perpustakaan di sekolah.

Indikator pertama yaitu persepsi masyarakat terhadap keterdukungan sarana dan prasarana terhadap sistem pembelajaran. Dari hasil penelitian maka diperoleh data sebagai berikut.

Tabel 14. Persepsi Masyarakat Terhadap Keterdukungan Sarana dan Prasarana Terhadap Sistem Pembelajaran

\begin{tabular}{lcc}
\hline $\begin{array}{c}\text { Sarana dan prasarana } \\
\text { sekolah di jenjang } \\
\text { pendidikan dasar } \\
\text { selama ini sudah } \\
\text { mampu mendukung } \\
\text { sistem pembelajaran } \\
\quad \text { siswa di sekolah }\end{array}$ & JUMLAH & PERSENTASE \\
SANGAT SETUJU & 12 & \\
SETUJU & 66 & $10 \%$ \\
KURANG SETUJU & 28 & $23 \%$ \\
TIDAK SETUJU & 13 & $11 \%$ \\
TIDAK TAHU & 1 & $1 \%$ \\
TOTAL & $\mathbf{1 2 0}$ & $\mathbf{1 0 0 \%}$ \\
\hline
\end{tabular}

Sumber: Data Olahan, 2015

Berdasarkan data di atas, dapat disimpulkan bahwa sebanyak $65 \%$ 
masyarakat menyatakan sangat setuju dan setuju bahwa sarana dan prasarana sekolah di jenjang pendidikan dasar selama ini sudah mampu mendukung sistem pembelajaran siswa di sekolah. Hanya 35\% yang menyatakan kurang setuju, tidak setuju dan tidak tahu.

Jika dilihat secara nyata, maka rata-rata sekolah dasar di Kota Tanjungpinang telah memiliki insfrastruktur yang memadai dalam mendukung sistem pembelajaran seperti telah memiliki laboratorium, fasilitas olahraga, perpustakaan, dan gedung Unit Kesehatan Siswa (UKS). Selain itu ruang kelas yang telah cukup baik dalam anggapan masyarakat. Fasilitas ini banyak didukug pemerintah lewat Dana Alokasi Khusus bidang pendidikan yang diberikan oleh pemerintah pusat kepada pemerintah daerah sehingga sekolah-sekolah dasar d Kota Tanjungpinang dapat memiliki infrastruktur yang cukup memadai.

Indikator selanjutnya dalam melihat pandangan masyarakat terhadap kebijakan standar nasional pendidikan di Kota Tanjungpinang adalah dengan mengukur pandangan masyarakat terhadap keterlibatan orang tua dan masyarakat dalam pemenuhan dan pemeliharaan sarana dan prasarana. Dari hasil penelitian diperoleh data sebagai berikut.

Tabel 15. Persepsi Masyarakat Terhadap Keterlibatan Orang Tua dan Masyarakat Dalam Pemenuhan dan Pemeliharaan Sarana dan Prasarana

\begin{tabular}{lcc}
\hline $\begin{array}{c}\text { Keterlibatan orang tua } \\
\text { dan masyarakat sangat } \\
\text { diperlukan dalam } \\
\text { pemenuhan dan }\end{array}$ & JUMLAH & PERSENTASE \\
$\begin{array}{c}\text { pemeliharaan sarana } \\
\text { dan prasana di sekolah } \\
\text { selain tanggung jawab } \\
\text { sekolah dan pemerintah }\end{array}$ & & \\
SANGAT SETUJU & 37 & $31 \%$ \\
SETUJU & 66 & $55 \%$ \\
KURANG SETUJU & 13 & $11 \%$ \\
TIDAK SETUJU & 4 & $3 \%$ \\
TIDAK TAHU & - & $0 \%$ \\
TOTAL & $\mathbf{1 2 0}$ & $\mathbf{1 0 0} \%$ \\
\hline SUmber: Data Olahan, 2015 & &
\end{tabular}

Sumber: Data Olahan, 2015

Berdasarkan tabel di atas, maka dapat disimpulkan bahwa sebanyak $86 \%$ masyarakat menyatakan sanga setuju dan setuju dengan pernyataan bahwa keterlibatan orang tua dan masyarakat sangat diperlukan dalam pemenuhan dan pemeliharaan sarana dan prasarana di sekolah selain menjadi tanggung jawab sekolah dan pemerintah. Sementara hanya $14 \%$ masyarakat yang menjawab kurang setuju dan tidak setuju. Keterlibatan orang tua dan masyarakat dalam pemenuhan dan pemeliharaan sarana dan prasarana di sekolah dapat diaktualisasikan dengan adanya komite sekolah yang menjadi mitra sekolah dalam pengambilan kebijakan di sekolah. Sekolah tidak mungkin mendapatkan bantuan terus menerus dari pemerintah, dan akan sangat sulit juga jika melalui iuran pendidikan. Dana Operasional Sekolah (BOS) yang diberikan oleh pemerintah tidak mampu mencukupi sepenuhnya kebutuhan siswa, oleh karena itu perlu adanya sinergitas antara orang tua siswa yang diwakili oleh Komite Sekolah untuk pemenuhan dan pemeliharaan sarana dan prasarana sekolah.

Indikator selanjutnya adalah dengan mengukur pandangan masyarakat terhadap keterlibatan orang tua dan masyarakat dalam pemenuhan buku dan perpustakaan di sekolah. Hasil penelitian menghasilkan data sebagai berikut.

Tabel 16. Persepsi Masyarakat terhadap Keterlibatan Orang Tua dan Masyarakat dalam Pemenuhan Buku Siswa dan Perpustakaan di Sekolah

\begin{tabular}{ccc}
\hline $\begin{array}{c}\text { Keterlibatan orang tua } \\
\text { dan masyarakat sangat } \\
\text { diperlukan dalam } \\
\text { memenuhi kebutuhan } \\
\text { buku siswa dan } \\
\text { perpustakaan sekolah } \\
\text { selain tanggung jawab } \\
\text { sekolah dan } \\
\text { pemerintah }\end{array}$ & JUMLAH & PERSENTASE \\
SANGAT SETUJU & 30 & \\
SETUJU & 60 & $50 \%$ \\
KURANG SETUJU & 21 & $18 \%$ \\
TIDAK SETUJU & 9 & $8 \%$ \\
TIDAK TAHU & - & $0 \%$ \\
TOTAL & $\mathbf{1 2 0}$ & $\mathbf{1 0 0} \%$ \\
\hline
\end{tabular}

Sumber: Data Olahan, 2015

Berdasarkan tabel di atas, tampak bahwa $75 \%$ masyarakat berpandangan sangat setuju dan setuju bahwa keterlibatan orang tua dan masyarakat sangat diperlukan 
dalam memenuhi kebutuhan buku siswa dan perpustakaan sekolah selain tanggung jawab sekolah dan pemerintah. Hanya 26\% masyarakat yang kurang setuju dan tidak setuju atas penyataan pada indikator ini. Dalam konteks ini artinya, pihak sekolah harus bekerja sama dengan orang tua murid melalui komite sekolah dalam pemenuhan buku, harus terjadi proses yang dialogis antara komite sekolah dan orang tua dan juga masyarakat sekitar sekolah, terkait dengan buku-buku. Alangkah baiknya jika komite sekolah dan masyarakat juga turut menyumbang buku karena bagaimana pun sekolah tidak memiliki kemampuan yang cukup besar dalam pemenuhan buku di sekolah.

\section{Aspek Pembiayaan}

Untuk mengukur persepsi masyarakat terhadap kebijakan standar pendidikan maka dimensi selanjutnya adalah dengan melakukan pengukuran terhadap aspek pembiayaan. Dalam aspek pembiayaan yang menjadi indikator adalah pertama, pembiayaan pendidikan yang adil, transparan, dan akuntabel, kedua, pengelolaan dana Bantuan Operasioanal Sekolah (BOS) yang baik, transparan, dan akuntabel dan berguna bagi siswa dalam menjalani pendidikan, ketiga, keterlibatan orang tua dan masyarakat dalam pengawasan dan audit keuangan termasuk dana BOS, dan keempat, ketepatanan sasaran Dana BOS terhadap kelompok sasaran. Berdasarkan hasil penelitian terhadap indikator pertama maka dihasilkan data sebagai berikut.

Tabel 17. Persepsi Masyarakat terhadap Pembiayaan Pendidikan yang Adil, Transparan, dan Akuntabel

\begin{tabular}{lcc}
\multicolumn{2}{c}{ Akuntabel } \\
\hline $\begin{array}{c}\text { Sekolah pada } \\
\text { jenjang pendidikan } \\
\text { dasar saat ini telah } \\
\text { melakukan standar } \\
\text { pembiayaan yang } \\
\text { baik dan transparan } \\
\text { dan akuntabel }\end{array}$ & JUMLAH & PERSENTASE \\
SANGAT SETUJU & 12 & $10 \%$ \\
SETUJU & 75 & $63 \%$ \\
KURANG SETUJU & 25 & $21 \%$ \\
TIDAK SETUJU & 7 & $6 \%$ \\
TIDAK TAHU & 1 & $1 \%$ \\
TOTAL & $\mathbf{1 2 0}$ & $\mathbf{1 0 0} \%$ \\
\hline
\end{tabular}

\section{Sumber: Data Olahan, 2015}

Berdasarkan data di atas, menunjukkan bahwa masyarakat berpandangan sangat setuju dan setuju sebanyak $73 \%$ terhadap penyataan bahwa sekolah pada jenjang pendidikan dasar saat ini telah melakukan standar pembiayaan yang baik dan transparan serta akuntabel, hanya $28 \%$ yang menyatakan kurang setuju, tidak setuju dan tidak tahu. Itu artinya masyarakat berpandangan bahwa pembiayaan yang selama ini ada di tingkat sekolah dasar telah adil, transparan dan akuntabel.

Indikator selanjutnya dalam melakukan pengukuran pandangan masyarakat terhadap kebijakan standar pendidikan khususnya pada pendidikan dasar, yaitu mengukur persepsi masyarakat terhadap keterlibatan orang tua dan masyarakat dalam pengawasan dan audit keuangan termasuk dana BOS. Hasil penelitian memberikan data sebagai berikut:

Tabel 18. Persepsi Masyarakat Terhadap Pengelolaan Dana Bantuan Operasioanal Sekolah (BOS) Yang Baik, Transparan, dan Akuntabel serta Berguna Bagi Siswa Dalam Menjalani Pendidikan

$$
\text { Sekolah pada }
$$

jenjang pendidikan

dasar telah berhasil

mengelola dana

Bantuan

Operasional Sekolah

dengan baik dan

JUMLAH PERSENTASE

transparan serta

akuntabel sehingga

memudahkan siswa

dalam menjalani

pendidikan

SANGAT SETUJU

SETUJU

KURANG SETUJU

TIDAK SETUJU

TIDAK TAHU

TOTAL

Sumber: Data Olahan, 2015

Berdasarkan data di atas, maka dapat disimpulkan bahwa $70 \%$ masyarakat berpandangan sangat setuju dan setuju bahwa sekolah pada jenjang pendidikan dasar telah berhasil mengelola dana Bantuan Operasional Sekolah dengan baik dan transparan serta akuntabel sehingga memudahkan siswa dalam menjalani pendidikan, hanya $30 \%$ yang menyatakan 
kurang setuju, tidak setuju dan tidah tahu akan penyataan tersebut. Hal ini dapat simpulkan juga bahwa masyarakat telah menyatakan bahwa sekolah pada tingkat pendidikan dasar selama ini telah dinyatakan berhasil mengelola Dana BOS dengan baik dan transparan dan masyarakat telah menyadari bahwa dana BOS telah memberikan manfaat baik secara langsung dan tak langsung.

$$
\text { Indikator selanjutnya adalah }
$$

pandangan masyarakat terhadap keterlibatan orang tua dan masyarakat dalam pengawasan dan audit keuangan termasuk dana BOS, dan hasil penelitian memberikan hasil sebagai berikut.

Tabel 19. Pandangan Masyarakat terhadap Keterlibatan Orang Tua dan Masyarakat Dalam Pengawasan dan Audit Keuangan Termasuk Dana BOS

\begin{tabular}{|c|c|c|}
\hline $\begin{array}{l}\text { Keterlibatan orang } \\
\text { dan masyarakat luas } \\
\text { sangat diperlukan } \\
\text { dalam pengawasan } \\
\text { dan audit keuangan di } \\
\text { sekolah termasuk } \\
\text { dana BOS }\end{array}$ & JUMLAH & PERSENTASE \\
\hline SANGAT SETUJU & 36 & $30 \%$ \\
\hline SETUJU & 66 & $55 \%$ \\
\hline KURANG SETUJU & 12 & $10 \%$ \\
\hline TIDAK SETUJU & 5 & $4 \%$ \\
\hline TIDAK TAHU & 1 & $1 \%$ \\
\hline TOTAL & 120 & $100 \%$ \\
\hline
\end{tabular}

Sumber: Data Olahan, 2015

Berdasarkan data di atas dapat disimpulkan bahwa $85 \%$ masyarakat berpandangan menyatakan sangat setuju dan setuju bahwa keterlibatan orang dan masyarakat luas sangat diperlukan dalam pengawasan dan audit keuangan di sekolah termasuk dana BOS. Hanya 25\% masyarakat menyatakan kurang setuju dan tidak setuju serta tidak tahu akan pernyataan ini. Hal ini menegaskan bahwa masyarakat menghendaki adanya keterlibatan orang tua dan masyarakat dalam pengawasan dan audit keuangan di sekolah termasuk pengelolaan Dana BOS. Pihak sekolah diharuskan transparan atas pengelolaan anggaran termasuk dana BOS. Daftar realisasi penggunaan Dana BOS harusnya ditampilkan di papan pengumuman dan juga diberikan kepada Komite Sekolah agar diketahui pihak orang tua siswa dan juga masyarakat. Selanjutnya Komite Sekolah dan Masyarakat juga diharapkan mampu memberikan masukan terhadap pengelolaan anggaran tersebut.

Indikator selanjutnya adalah mengukur persepsi masyarakat terhadap ketepatan sasaran dana BOS terhadap kelompok sasaran. Hasil penelitian menyajikan data sebagai berikut.

Tabel 20. Persepsi Masyarakat Terhadap Ketepatan Sasaran Dana BOS Terhadap Kelompok Sasaran

\begin{tabular}{|c|c|c|}
\hline $\begin{array}{c}\text { Dalam } \\
\text { pelaksanaannya } \\
\text { Dana BOS telah tepat } \\
\text { pada sasarannya } \\
\text { sehingga saat } \\
\text { membantu kelompok } \\
\text { sasaran tersebut } \\
\text { menjalani pendidikan } \\
\text { dasar }\end{array}$ & JUMLAH & PERSENTASE \\
\hline SANGAT SETUJU & 32 & $27 \%$ \\
\hline SETUJU & 51 & $43 \%$ \\
\hline KURANG SETUJU & 22 & $18 \%$ \\
\hline TIDAK SETUJU & 11 & $9 \%$ \\
\hline TIDAK TAHU & 4 & $3 \%$ \\
\hline TOTAL & 120 & $100 \%$ \\
\hline
\end{tabular}

Berdasarkan data di atas, dapat diketahui bahwa sebanyak 70\% masyarakat menyatakan sangat setuju dan setuju jika dalam pelaksanaannya Dana BOS telah tepat pada sasarannya sehingga saat membantu kelompok sasaran tersebut menjalani pendidikan dasar. Hanya 30\% masyarakat menyatakan kurang setuju, tidak setuju dan tidak tahu. Hal ini dapat menyatakan bahwa pengelolaan dana BOS telah sesuai sasaran dengan sasaran yang diatur dalam aturan yang berlaku. Dana BOS seyogyanya diperuntukkan untuk masing-masing siswa dengan jumah Rp 800.000,-/siswa/tahun. Pengelolaan ini dinilai oleh masyarakat sudah tepat sasaran. Hal ini disebabkan karena dana BOS bukan didistribusikan dalam bentuk uang kepada siswa, namun lebih kepada kebutuhan siswa seperti buku teks, langganan publikasi berkala, pemeliharaan buku/koleksi perpustakaan, peningkatan kompetensi tenaga pustakawan, pemeliharaan perabot perpustakaan dan pemeliharaan sarana dan sarana 
perpustakaan. Namun meski pendapat masyarakat menyatakan sudah tepat sasaran, perlunya kiranya pengawasan yang kuat baik internal dan eksternal terhadap pengelolaan dana BOS tersebut.

\section{Aspek Pengelolaan}

Aspek selanjutnya untuk mengukur kebijakan standar nasional pendidikan khususnya di tingkat pendidikan dasar yaitu dengan melakukan pengukuran aspek pengelolaan. Di dalam aspek pengelolaan indikator yang diukur terdiri dari dua indikator yaitu pertama, kemampuan sekolah mengelola dan mengembangkan pendidikan dasar, dan kedua, keterlibatan orang tua dalam proses perencanaan, pelaksanaan, dan evaluasi pengelolaan sekolah.

Berdasarkan hasil penelitian terhadap pengukuran indikator pertama diperoleh data sebagai berikut.

Tabel 21. Persepsi Masyarakat Terhadap Kemampuan Sekolah Mengelola dan Mengembangkan Pendidikan Dasar

\begin{tabular}{lcc}
\hline $\begin{array}{c}\text { Sekolah telah mampu } \\
\text { mengelola dan } \\
\text { mengembangkan } \\
\text { pendidikan dasar } \\
\quad \text { dengan baik }\end{array}$ & JUMLAH & PERSENTASE \\
SANGAT SETUJU & 27 & $23 \%$ \\
SETUJU & 76 & $63 \%$ \\
KURANG SETUJU & 8 & $7 \%$ \\
TIDAK SETUJU & 7 & $6 \%$ \\
TIDAK TAHU & 2 & $2 \%$ \\
TOTAL & $\mathbf{1 2 0}$ & $\mathbf{1 0 0 \%}$ \\
\hline Sumber: Data Olahan, 2015 & & \\
\hline
\end{tabular}

Sumber: Data Olahan, 2015

Berdasarkan data di atas, dapat disimpulkan bahwa $86 \%$ masyarakat menyatakan sangat setuju dan setuju bahwa sekolah telah mampu mengelola dan mengembangkan pendidikan dasar dengan baik. Hanya $14 \%$ yang menyatakan kurang setuju, tidak setuju dan tidak tahu. Ini artinya sekolah dasar di Kota Tanjungpinang, telah dinilai masyarakat mampu mengelola sumber daya manusia, sumber daya finansial, dan sumber daya sarana dan prasarana. Kepercayaan masyarakat terhadap institusi pendidikan sekolah dasar masih bernilai tinggi.

Indikator selanjutnya adalah mengukur persepsi masyarakat terhadap keterlibatan orang tua dalam proses perencanaan, pelaksanaan, dan evaluasi pengelolaan sekolah. Hasil penelitian menyajikan data sebagai berikut.

Tabel 22. Persepsi Masyarakat terhadap Keterlibatan Orang Tua Dalam Proses Perencanaan, Pelaksanaan, dan Evaluasi Pengelolaan Sekolah

\begin{tabular}{lcc}
\hline $\begin{array}{c}\text { Melibatkan peran } \\
\text { orang tua dan } \\
\text { masyarakat secara } \\
\text { lebih luas dalam } \\
\text { perencanaan, } \\
\text { pelaksanaan dan } \\
\text { evaluasi pengelolaan } \\
\text { sekolah pada jenjang } \\
\text { pendidikan dasar }\end{array}$ & JUMLAH & PERSENTASE \\
$\quad \begin{array}{c}\text { adalah sangat } \\
\text { diperlukan }\end{array}$ & & \\
SANGAT SETUJU & 44 & $37 \%$ \\
SETUJU & 68 & $57 \%$ \\
KURANG SETUJU & 7 & $6 \%$ \\
TIDAK SETUJU & - & $0 \%$ \\
TIDAK TAHU & 1 & $1 \%$ \\
TOTAL & $\mathbf{1 2 0}$ & $\mathbf{1 0 0} \%$ \\
\hline
\end{tabular}

Sumber: Data Olahan, 2015

Berdasarkan data di atas, dapat disimpulkan bahwa 94\% masyarakat berpandangan bahwa dalam sebuah manajemen pendidikan perlu pelibatan orang tua dan masyarakat secara lebih luas dalam hal perencanaan, pelaksanaan dan evaluasi pengelolaan sekolah pada jenjang pendidikan dasar. Hanya 4\% masyarakat menjawab kurang setuju. Hal ini mengisyaratkan bahwa orang tua dan masyarakat punya keinginan untuk membangun kualitas pendidikan selalu menjadi mitra sekolah dalam perencanaan, pelaksanaan dan evaluasi.

\section{Analisis Pandangan Masyarakat Terhadap Kebijakan Standar Nasional Pendidikan Dasar Di Kota Tanjungpinang}

Hasil penelitian dengan pendekatan kuantitatif di atas, sudah memberikan penjelasan yang komprehensif tentang pandangan masyarakat terhadap kebijakan standar nasional pendidikan dasar di Kota Tanjungpinang. Kebijakan standar nasional pendidikan ini penting untuk diberikan tanggapan masyarakat karena dengan 
standar inilah, kita dapat mengetahui bagaimana sebenarnya sebuah proses penyelenggaraan pendidikan di setiap jenjang pendidikan dilaksanakan, standar nasional pendidikan ini merupakan sebuah bagian yang tak terpisahkan dalam sebuah kebijakan pemerintah di bidang pendidikan, dimana kebijakan pendidikan itu sendiri dimaknai sebagai sebuah aturan hukum yag mengatur pelaksanaan sistem pendidikan, yang tercakup di dalamnya tujuan pendidikan dan bagaimana mencapai tujuan tersebut (Putera dan Valentina, 2010). Saat ini kebijakan standar nasional pendidikan nasional diaktualisasi dalam Peraturan Pemerintah Nomor 32 Tahun 2013 dan kemudian disempurnakan menjadi Peraturan Pemerintah Nomor 15 Tahun 2015. Tujuan standar ini menjamin mutu pendidikan nasional dalam rangka mencerdaskan kehidupan bangsa dan membentuk karakter serta peradaban bangsa yang bermartabat.

Dalam standar kurikulum yang diukur dalam hal ini adalah berkaitan dengan aspek isi kurikulum, aspek pembelajaran, aspek proses penilaian dan aspek lulusan. Dalam aspek isi kurikulum yang perlu dilihat adalah kesesuaian isi kurikulum dengan tantangan masa depan. Kurikulum sejatinya dilaksanakan dalam rangka membantu peserta didik mengembangkan berbagai potensi psikis dan fisik yang meliputi moral dan nilai-nilai agama, sosial-emosional, kognitif, bahasa, fisik atau motorik, kemandirian dan seni (Triwiyanto, 2013). Dalam konteks penelitian ini masyarakat menyatakan positif bahwa kurikulum pendidikan dasar di Kota Tanjungpinang sudah sesuai dan mampu menjawab tantangan masa depan. Berbicara tantangan masa depan, maka kurikulum harus melampaui apa yang ditetapkan dalam standar lulusan. Kurikulum harus menjadi "nafas" atau "inti" dari proses pendidikan di sekolah untuk memberdayakan potensi peserta didik (Triwiyanto, 2013). Potensi yang dikembangkan kurikulum harus menjawab tantangan masa depan bangsa seperti Masyarakat Ekonomi Asia (MEA) yang tentunya dibutuhkan kemampuan berbahasa asing yang baik untuk dimiliki oleh sumber daya manusia di Kota Tanjungpinang. Kurikulum juga harus mampu menjawab dan mencerminkan keinginan, cita-cita, tuntutan, dan kebutuhan masyarakat (Nasution, 1995, Triwiyanto, 2013). Kemudian pandangan masyarakat juga positif terhadap aspek kurikulum dalam konteks keterlibatan orang tua dan masyarakat dalam pengembangan pendidikan. Sebagaimana dijelaskan oleh Nasution (1995) dan Triwiyanto (2013) menyatakan bahwa sekolah didirikan juga oleh dan untuk masyarakat sudah sewajarnya pendidikan memperhatikan dan merespon suara-suara dalam masyarakat. Itu artinya, masyarakat dan orang tua sebagai warga pendidikan di sekolah tertentu, punya peran dalam mengembangkan kurikulum dalam pendidikan dasar. Khususnya orang tua melalui komite sekolah, perlu menyampaikan hal-hal yang memang mendalam dalam aspek kurikulum agar arah dan tujuan pendidikan juga disesuaikan dengan kebutuhan pasar dan tantangan masa depan. Hubungan lembaga pendidikan dengan masyarakat adalah suatu proses komunikasi dengan tujuan untuk meningkatkan pemahaman masyarakat terhadap kebutuhan dan praktik pendidikan dan pada akhirnya bekerja sama untuk meningkatkan kualitas pendidikan di lembaga pendidikan (Maysaroh dalam Triwiyanto, 2013). Keterlibatan dalam omunikasi antara lembaga pendidikan dan sekolah dapat diciptakan dalam bentuk persatuan orang tua peserta didik, komite atau dewan sekolah, dewan pendidikan atau lembaga swadaya masyarakat yang fokus pada bidang pendidikan (Triwiyanto, 2013).

Dalam konteks aspek pembelajaran, masyarakat Kota Tanjungpinang memberikan pandangan terkait dengan metode pembelajaran yang terpusat pada guru (teacher centre learning), berpusat pada siswa (student centre learning) dan keterlibatan orang dan masyarakat dalam merancang proses pembelajaran. Berdasarkan hasil penelitian tampak bahwa masyarakat Kota Tanjungpinang lebih banyak menyatakan positif dengan sistem pembelajaran yang berpusat pada siswa (student centre learning) sementara guru lebih berperan sebagai fasilitator dalam proses pembelajaran. Berdasarkan penelitian yang dijelaskan oleh Lubis (2013) menyatakan bahwa banyak kelemahan yang terjadi dalam proses pembelajaran di lembaga pendidikan saat ini salah satunya adalah kelemahan guru yang mengajar 
dengan cara-cara lama serta kurang melibatkan peserta didik secara aktif, sehingga berpengaruh kepada iklim belajar yang kurang kondusif. Dengan demikian jelas bahwa metode yang lebih terbarukan adalah harusnya menjadikan peserta didik sebagai subjek proses pendidikan dengan keterlibatan yang lebih aktif. Proses pembelajaran yang diinginkan masyarakat adalah siswa terlibat dalam penemuanpenemuan ilmu pengetahuan secara langsung yang dilakukan oleh dirinya. Sementara guru menjadi pengarah dan fasilitator siswa untuk menemukan ilmu pengetahuan tersebut. Selanjutnya Lubis (2013) juga menjelaskan tentang keterlibatan orang tua dan masyarakat dalam perancangan proses pembelajaran. Lubis (2013) menjelaskan bahwa sistem monitoring kinerja guru selain bersifat top-down yang diawasi secara langsung oleh kepala sekolah, dapat juga dilakukan dengan pendekatan lain yang melibatkan stakeholder (guru, penilik sekolah, komite sekolah dan wakil pemerhati pendidikan) sebagaimana dilakukan di tiga negara bagian di Virginia Amerika Serikat. Keterlibatan kelompok stakeholder ini membawa dampak positif terhadap sistem monitoring. Kelompok yang disebut Educational Performance Recognition mengajukan 3 komponen sistem monitoring yaitu indikator hasil belajar dan kemajuan belajar, dan penetapan sistem standar kinerja.

Dalam aspek penilaian pendidikan, masyakat memberikan pandangan terkait dengan metode penilaian yang hanya berdasarkan pada hasil pembelajaran, berdasarkan pada kerajinan dan perilaku siswa, dan berdasarkan kolaborasi dari hasil pembelajaran, kerajinan dan perilaku siswa. Tanggapan positif tertinggi dari masyarakat adalah terkait dengan proses penilaian didasarkan atas kolaborasi proses pembelajaran, kerajinan dan perilaku siswa. Pandangan masyarakat dalam konteks ini senada dengan apa yang dijelaskan oleh Zahriyanti (2014) dalam sebuah penelitian yang menyatakan bahwa pembagian penilaian kepada siswa terbagi atas beberapa hal yaitu penilaian unjuk kerja, penilaian sikap, penilaian tertulis, penilaian proyek, penilaian produk, penilaian portofolio dan penilaian diri. Zahriyanti (2014) menjelaskan dengan detail bahwa penilaian unjuk kerja merupakan penilaian yang dilakukan dengan mengamati kegiatan peserta didik, penilaian sikap merupakan penilaian yang diambil dari sisi afektif, kognitif, dan konatif, penilaian tertulis merupakan penilaian yang diperoleh dari dilakukannya tes tertulis, penilaian proyek merupakan kegiatan penilaian terhadap suatu tugas yang harus diselesaikan dalam periode dan waktu tertentu, penilaian produk merupakan penilaian terhadap proses pembuatan produk dengan tiga tahapan yaitu tahapan persiapan, tahap pembuatan, dan tahap penilaian, penilaian portofolio merupakan penilaian berkelanjutan yang didasarkan pada kumpulan informasi yang menunjukkan perkembangan kemampuan peserta didik dalam suatu periode tertentu. Itu artinya proses penilaian meliputi banyak hal, proses yang sangat komprehensif dengan memadukan berbagai aspek dalam proses penilaian. Perpaduan banyak aspek penilaian tersebut memiliki fungsi tersendiri sebagaimana dijelaskan oleh Zahriyanti (2014) yaitu, untuk mengetahui kemampuan belajar siswa, mengdiagnosis kesulitas belajar, memberikan umpan balik, melakukan perbaikan dan memotivasi siswa belajar lebih baik.

Dalam aspek kelulusan, masyarakat memberikan pandangan bahwa sistem kelulusan sekolah di Indonesia masih terbilang kaku dengan hanya mempertimbangkan nilai UASBN atau disebut juga Ujian Nasional. Meskipun masyarakat memberikan pandangan bahwa lulusan sekolah termasuk sekolah dasar telah mampu mencerminkan kualitas masa depan bangsa. Namun jika hanya mempertimbangkan nilai akhir, maka jelas lulusan sekolah di Indonesia hanya akan menjadi lulusan yang hanya memiliki ilmu namun miskin akan kompetensi praktis kurikulum. Relevansi kurikulum yang berorientasi pada kebutuhan lapangan kerja yang dapat menjamin mutu lulusan yang siap masuk ke dunia kerja atau ke jenjang pendidikan yang lebih tinggi. Sekolah yang berkualitas menyajikan kurikulum dan aktivitas akademik yang merupakan hak mendasar bagi siswa, yang dapat menjadi jaminan tercapainya kualitas pendidikan bermutu dengan kebutuhan. Kurikulum yang baik yang menjamin 
tercapainya lulusan yang berkualitas adalah kurikulum yang berorientasi kepada kebutuhan peserta didik untuk memperoleh pengetahuan, sikap, dan keterampilan yang bersifat universal yang sangat diperlukan siswa untuk mengembangkan intelektual, sistem nilai, dan keterampilan yang dibutuhkan dalam kehidupan secara luas, dan terutama mempersiapkan siswa menapaki jenjang pendidikan yang lebih tinggi (Lubis, 2013).

Pada tataran standar Tenaga Pendidik dan Tenaga Kependidikan maka masyarakat Kota Tanjungpinang memandang bahwa kuantitas dan kualitas guru pada pendidikan dasar sudah dinilai memadai dalam menyelenggarakan proses belajar mengajar. Dalam hal ini masyarakat juga sepakat bahwa dalam peningkatan tenaga pendidik dan tenaga kependidikan, maka perlu peran pemerintah, orang tua dan masyarakat. Pemerintah tentunya mampu mengembangkan kompetensi tenaga pendidik dan tenaga kependidikan dengan menciptakan suatu instrumen-instrumen peningkatan kompetensi. Sebagaimana yang dijelaskan oleh Lubis (2013) bahwa pemerintah dalam hal ini menyediakan standarisasi tenaga pendidik dan tenaga kependidikan secara nasional dan intenasional, lembaga tersertifikasi dalam menunjang dan meningkatkan kompetensi tenaga pendidik dan tenaga kependidikan. Selain itu pembinaa dan pengembangan profesi guru sebagai suatu bidang profesional ke depan perlu kiat dan tatanan sistem keprofesian guru yang jelas, misalnya pengembangkan kerja kolaboratif pengajaran, konsultasi dan in-service training serta upgrading kompetensi. Selain itu penting juga sistem penghargaan terhadap pekerjaa profesi, sistem promosi dan gaji bagi tenaga guru merupakan isu yang turut menentukan kualitas guru (Lubis, 2013).

Dalalm konteks standar sarana dan prasarana masyarakat menyatakan sebuah penilaian yang terbilang positif untuk sekolah-sekolah dasar di Kota Tanjungpinang terkait dengan sarana dan prasarana, dimana masyarakat menyatakan bahwa sarana prasarana sudah mampu mendukung proses pembelajaran di sekolah dasar seperti perpustakaan, buku-buku, unit kesehatan siswa, namun masyarakat juga memberikan pandangan bahwa dalam pemenuhan buku dan sarana prasarana lainnya perlu adanya keterlibatan orang tua dan masyarakat. Konsep pengembangan sarana dan prasarana di sekolah jika kita bercermin pada konsep Irianto dan Sa'ud dalam Triwiyanto (2013) terdapat beberapa prinsip yaitu:

1. Relevance yaitu pengembangan dan inovasi sarana dan prasarana pendidikan harus sesuai dengan kebutuhan penyelenggaraan pendidikan,

2. Manageble yaitu pengembangan dan inovasi sarana dan prasarana pendidikan merupakan bagian dalam pengembangan fungsi manajemen kelembagaan,

3. Suistanable yaitu pengembangan dan inovasi sarana dan prasarana pendidikan harus dapat dilihat dari keberlanjutan programnya,

4. Efficiency yaitu pengembangan dan inovasi sarana dan prasaran pendidikan harus memperhatikan unsur efisiensi dalam kelembagaan,

5. Productivity yaitu pengembangan dan inovasi sarana dan prasarana pendidikan harus mengacu kepada peningkatan output,

6. Up to Date yaitu pengembangan dan inovasi sarana dan prasarana pendidikan dikembangkan merupakan hal yang terbaru dalam penyelenggaraan pendidikan.

Pada standar pembiayaan, hasil penelitian memberikan deskripsi bahwa masyarakat menilai standar pembiayaan sudah mampu dikelola oleh sekolah dengan baik, serta dana BOS telah mampu memberikan manfaat kepada siswa, serta perlunya transparansi kepada orang tua dan masyarakat terhadap pengelolaan anggaran di sekolah. Berbicara pembiayaan pendidikan, maka harusnya pembiayaan pendidikan ini dijalankan sesuai dengan 
amanat Undang-Undang Dasar 1945 Pasal 31 Ayat 4 yang menyatakan bahwa negara memprioritaskan sekurang-kurangnya dua puluh persen dari anggaran pendapatan dan belanja negara serta dari anggaran pendapatan dan belanja daerah untuk memenuhi kebutuhan penyelenggaraan pendidikan nasional. Namun selama ini pembiayaan pendidikan yang diusahakan pemerintah masih terbatas pada bantuan investasi penyediaan sarana dan fasilitas serta peralatan pendidikan, serta biaya operasional penyelenggaraan pendidikan yang mendukung terselenggaranya proses pembelajaran yang baik dan berhasil. Satu faktor seakan terlupakan adalah biaya personal yang langsung dapat menjamin kesiapan peserta didik untuk terlibat dalam aktivitas pembelajaran (Lubis, 2013). Pada penelitian lainnya yang dilakukan oleh Putera dan Valentina (2010) membuktikan bahwa pembiayaan pendidikan lewat Dana BOS memberikan pengaruh yang signifikan terhadap pembiayaan pendidikan di tingkat sekolah dasar. Sehingga sekolah dasar tidak perlu lagi melakukan punguta terhadap siswa yang ada karena sudah cukup dengan Dana BOS dari Pemerintah Pusat. Putera dan Valentina (2010) juga menjelaskan bahwa dengan adanya bantuan dana dekonsentrasi dan hibah dari pemerintah pusat dinilai cukup membantu sekolah dalam proses belajar mengajar terkait dengan biaya operasional sekolah, sehingga dari beberapa sekolah tidak perlu lagi memungut biaya dari siswa karena sudah cukup terbantu dari bantuan pemerintah tersebut, namun ada juga sekolah yang memungut biaya dari siswa karena sekolah menilai bantuan Dana BOS dari pemerintah pusat belum mencukupi untuk membiayai keperluan atau operasional sekolah. Perbedaan tersebut tergantung dari kebutuhan masing-masing sekolah, sehingga jika kebutuhan sekolah besar, maka perlu sumber lain yang mungkin dioptimalkan.

Aspek terakhir adalah standar pengelolaan pendidikan. Masyarakat Kota Tanjungpinang memberikan jawaban yang juga positif yang menunjukkan bahwa pengelolaan pendidikan tingkat dasar sudah baik. Berbicara masalah standar pengelolaan pendidikan, maka pengelolaan pendidikan yang baik adalah dengan Manajemen Berbasis Sekolah atau sering disingkat MBS.
MBS biasanya dimulai dengan desentralisasi dan dilanjutkan dengan pelimpahan kekuasaan tertentu dari pusat ke sekolah. MBS merupakan suatu model manajemen yang memberikan otonomi lebih besar kepada sekolah dan mendorong pengambilan keputusan partisipatif oleh semua stakeholders seperti Guru, Komite Sekolah, Pengawas Sekolah, Penilik Sekolah, dan juga masyarakat (Rahayu, 2013). MBS di Indonesia lebih menekankan pada pemberian kewenangan, kepercayaan, dan kemandirian kepada sekolah untuk mengelola dan mengembangkan pendidikan dalam rangka meningkatkan mutu pendidikan di sekolah masing-masing. Oleh karena itu dalam rangka optimalisasi MBS maka perlu penguatan kepemimpinan kepala sekolah, dan tersedianya segala sumber daya yang merupakan prasyarat keberhasilan pelaksanaan MBS (Umaedi dalam Rahayu, 2013).

\section{SIMPULAN DAN SARAN}

\section{Simpulan}

Penelitian persepsi masyarakat Kota Tanjungpinang terhadap Kebijakan Standar Nasional Pendidikan di Kota Tanjungpinang Tahun 2015 menunjukkan bahwa masyarakat juga tanggap akan penyelenggaraan pendidikan di Kota Tanjungpinang. Penelitian ini menyimpulkan bahwa masyarakat berpandangan bahwa kurikulum yang dilaksanakan oleh pendidikan dasar di Kota Tanjungpinang sudah sesuai dengan tantangan masa depan, namun masyarakat berpandangan perlu dilibatkan dalam pengembangan kurikulum yang akan dituangkan ke dalam proses pembelajaran di sekolah. Dalam proses pembelajaran masyarakat berpandangan metode pembelajaran student centre learning mampu dioptimalkan karena dengan metode ini, siswa menemukan ilmu pengetahuan lewat pengalaman yang ia alami secara mandiri dan peran guru mengarahkan bagaimana siswa menemukan ilmu pengetahuan tersebut. Masyarakat juga berpandangan bahwa dalam proses penilaian yang perlu diperhatikan adalah tidak hanya sifatnya kognitif akan tetapi juga dalam tataran etika, perilaku dan karakter siswa sehingga lulusan yang diharapkan oleh masyarakat Kota 
Jurnal Ilmu Pemerintahan, 2 (1), April 2017 - 82

Rendra Setyadiharja, M.IP dan Dr. Neng Suryanti Nengsih, M.Si

Tanjungpinang mampu mencerminkan kualitas pendidikan dasar di Kota Tanjungpinang. Menunjang penyelenggaran pendidikan di Kota Tanjungpinang, masyakarat berpandang kualitas dan kuantitas tenaga pendidikan dan tenaga kependidikan sudah dinilai baik dan miliki kompetensi dalam mengelola pendidikan di sekolah dasar, dengan sarana dan prasarana yang menurut masyarakat juga sudah baik, maka akan mampu melakukan penyelenggaraan pendidikan di sekolah dasar. Standar pembiayaan pendidikan lewat Dana BOS pun sudah mampu memberikan manfaat kepada siswa dalam memenuhi kebutuhan buku dan sarana prasarana penunjang pembelajaran di sekolah. Selanjutnya dengan pendekatan Manajamen Berbasis Sekolah maka diharapkan semua stakeholders mampu terlibat aktif dalam penyelenggaraan pendidikan sehingga pelaksanaan pendidkan berjalan sebagaimana mestinya.

\section{Saran}

Penelitian ini memberikan saran antara lain, pertama, pengembangan kurikulum dalam standar pendidikan hendaknya tidak kaku, dapat melibatkan orang tua, komite sekolah dan juga masyarakat, agar siswa mendapat ilmu yang benar-benar menjawab tantangan masa depannya, kedua, proses pembelajaran sedapat mungkin keterlibatan siswa lebih dominan dengan guru sebagai fasilitator, ketiga, aspek penilaian dan kelulusan diharapkan tidak hanya aspek kognitif namun juga diharapkan nilai-nilai karakter anak bangsa dapat juga menjadi sebuah penilaian, keempat, guru senantiasa mendapatkan perhatian dalam menunjang kemampuan dan kompetensi mereka, kelima, transparansi dan akuntabilitas senantiasa dapat dilakukan dengan juga melibatkan orang tua, komite sekolah dan masyarakat sebagai pengawas dalam pelaksanaan dan penggunaan dana BOS, sehingga anggaran ini tidak menguap untuk hal-hal yang menyimpang. Terakhir, manajemen berbasis sekolah dengan pelibatan multi stakeholders perlu dikuatkan, sehingga sekolah tidak hanya dijalankan oleh pihak sekolah semata, namun masyarakat dan orang tua juga mengetahui bagaimana proses pendidikan dijalankan demi peningkatan kualitas pendidikan.

\section{DAFTAR PUSTAKA}

Arens, dan Loebbecke. (1997), Auditing dialih bahasakan oleh Amir Yusuf, Edisi Indonesia. Jakarta: Penerbit Salemba Empat

Data Pendidikan Kota Tanjungpinang 2014

Handayaningrat, Soewarno. (1995). Azas-azas Organisasi Manajemen. Jakarta. CV Mas Agung

Lubis, A. (2013). Pelaksanaan Standar Nasional dalam Dunia Pendidikan.

Nasution, M. A. (1995). Kurikulum dan pengajaran. Jakarta. Bumi Aksara.

Paparan Menteri Pendidikan Dan Kebudayaan, (2013), Pengembangan Kurikulum 2013

Peraturan Pemerintah Nomor 13 Tahun 2015 tentang Perubahan Kedua Atas Peraturan Pemerintah Nomor 19 Tahun 2005 Tentang Standar Nasional Pendidikan

Peraturan Pemerintah Nomor 19 Tahun 2005 tentang Standar Nasional Pendidikan

Peraturan Pemerintah Nomor 32 Tahun 2013 tentang Perubahan Atas Peraturan Pemerintah Nomor 19 Tahun 2005 Tentang Standar Nasional Pendidikan

Peraturan Presiden Nomor 5 Tahun 2010 tentang Rencana Pembangunan Jangka Menengah Nasional

Permendiknas No 71 tahun 2013 mengenai Struktur Kurikulum

Putra, R. E., \& Valentina, T. R. (2010). Pembiayaan Pendidikan di Era Otonomi Daerah: Studi Kasus di Kabupaten Solok. Jurnal Demokrasi, 9(1).

Rahayu, M. (2013). Pelaksanaan Standar Pengelolaan Pendidikan Di Sekolah Dasar Kecamatan Ngemplak, Kabupaten Sleman (Doctoral dissertation, UNY).

Richard, M. Steers. (1980). Efektivitas Organisasi. Jakarta. Erlangga

Supriyono. (2000). Sistem Pengendalian Manajemen. Jakarta: Erlangga.

Triwiyanto, T. (2013). Standar Nasional Pendidikan sebagai Indikator Mutu Layanan Manajemen Sekolah. Jurnal Ilmu Pendidikan, 19(2).

Undang-Undang Dasar 1945

Undang-Undang nomor 20 tahun 2003 tentang Sistem Pendidikan Nasional 
Jurnal Ilmu Pemerintahan, 2 (1), April 2017 - 83

Rendra Setyadiharja, M.IP dan Dr. Neng Suryanti Nengsih, M.Si

Wahab, Solichin Abdul. (2004). Analisis Kebijakan Dari Formulasi ke Implementasi Kebijakan Negara. Jakarta: PT Bumi Aksara.

Zahriyanti, M. A. (2015). Sistem Penilaian Berstandar Nasional Dalam Pendidikan. JURNAL LENTERA, 14(1).

\section{PROFIL SINGKAT}

RENDRA SETYADIHARJA, S.Sos., M.I.P, Lahir di Tanjungpinang tanggal 20 Maret 1986, merupakan seorang penyair dan juga dosen pada Sekolah Tinggi Ilmu Sosial dan Ilmu Politik Raja Haji Tanjungpinang Kepulauan Riau. Menyelesaikan pendidikan dasar di SDN 003 Tiban Batam (lulus tahun 1999), kemudian melanjutkan ke Madrasah Tsanawiyah Negeri Tanjungpinang (lulus tahun 2002), selanjutnya melanjutkan pendidikan menengah atas di SMA Negeri 1 Tanjungpinang (lulus tahun 2005). Penulis menyelesaikan pendidikan Strata 1 di STISIPOL Raja Haji Tanjungpinang pada Program Studi Ilmu Pemerintahan (lulus tahun 2010), kemudian menyelesaikan magisternya di Magister Ilmu Pemerintahan Universitas Muhammadiyah Yogyarakarta (lulus tahun 2014) dengan predikat Cumlaude dan Terbaik.

\section{DR. NENG SURYANTI NENGSIH, M.Si}

Merupakan dosen Stisipol Raja Haji Tanjungpinang, menamatkan pendidikan doktoralnya di Universitas Padjajaran Bandung. Saat ini sebagai pengajar aktif di Program Studi Ilmu Pemerintahan Stisipol Raja Haji Tanjungpinang. Aktif dalam Seminar Internasional seperti International Conference On Public Organization VI di Thailand tahun 2016, International Conference On Social Politics di Universitas Muhammadiyah Yogyakarta Tahun 2015. 